\title{
Social compliance audits and multinational company supply chain: Evidence from a study of the rituals of social audits
}

\begin{abstract}
This study investigates the use of social compliance audits in the supply chain of multinational companies (MNCs). Particularly, we explore the use of such audits in assessing and managing the working conditions of factory workers in the garment industry in a developing nation. Through a range of interviews with MNCs' internal auditors, with commissioned external auditors and with representatives of the suppliers in Bangladesh, this study finds that social compliance audits become ritual strategies and are not a primary means of advancing workers' rights. Drawing on the concept of surrogate accountability, the study suggests that to create real change in workers' conditions and in order to hold MNCs and their suppliers accountable, some form of surrogate (government, NGOs or media) intervention is necessary. This is, we argue, preferable to leaving it in the hands of 'markets' and simply waiting for another major incident such as Rana Plaza to stir public concern. This study contributes to the literature by investigating how social compliance audits are undertaken by MNCs sourcing products from a developing nation, what motivations drive the adoption of such audits, and what, if anything, are the likely outcomes from the process.
\end{abstract}

Keywords: Social compliance audits, Surrogate accountability, Supply chain, Developing nations.

\section{For Citation:}

Islam M.A. Deegan, C., \& Gray, R. (forthcoming, 2018) 'Social compliance audits and multinational company supply chain: Evidence from a study of the rituals of social audits", Accounting and Business Research 


\section{Introduction}

Within the business and accounting literature there is a growing body of research investigating audit and attestation activities including such things as social compliance audits, sustainability assurance and certification practices (Owen et al., 2000; Gray, 2000; Deegan et al. 2006a, b; O'Dwyer \& Owen, 2005; Owen, 2007; Simnett et al., 2009; Edgley et al., 2010; O'Dwyer et al., 2011). Such research of social compliance audit or assurance practices has embraced accountability perspectives with the associated normative emphasis (Gray, 2000; Owen et al., 2000; Edgley et al., 2010) as well as legitimacy or reputation-building aspects (O’Dwyer et al., 2011; Simnett et al, 2009; Darnall, et al., 2009). Generally speaking, research has typically overlooked the details of the social compliance audit process itself. There is relatively sparse understanding of how social compliance audits are undertaken and whether and how managers and auditors are held accountable for their actions in the audit process. Furthermore, little seems to be known about how the social compliance audit process impacts on the power relations between managers and less powerful stakeholders such as workers. This study seeks to fill this research gap and, through a series of interviews with retail garments MNCs and their suppliers' auditors in a developing country (Bangladesh in this case), this study seeks to shine a light back onto MNC practices and, incidentally, expose the emptiness of some of those claims made by MNCs about their supply chain.

As international organisations and markets get bigger and as the remoteness between civil society and its dominant economic organs gets ever greater (Beder, 2006) so, it seems, does the need for these organisations to profess their social and environmental credentials. One does not need to have a view either way on the social responsibility of business to recognise that corporate social responsibility (CSR) particularly in the global supply chains is big business (Banerjee, 2007). Equally, one does not have to have a particular view on the argument that organisations only exist at the behest - and with the approval - of their stakeholders (Blowfield \& Murray, 2008) to recognise that social compliance credentials are amongst the characteristics that organisations use in their negotiations of - and with - markets and civil society (Thielemann, 2000). Initiatives as diverse as, for example, the Marine and Forestry Stewardship Councils, Soil Association accreditation, BSCI standards, Global Reporting Initiatives (GRI), the Global Compact and ISO 14001 are, regardless of any judgement of their efficacy, substantive phenomena with which an increasing number of large organisations empirically engage. However, these initiatives are unlikely, in and of themselves, to have the capacity to challenge embedded working condition and social discrimination within the production process and supply chains (Barrientos and Smith, 2007). In this paper, we aim to explore this tension further by looking at the compliance auditing process (rather than codes and compliance in general ${ }^{1}$ ) within the $\mathrm{MNCs}^{\prime}$ clothing supply chains in a developing nation. The investigation of the social compliance audits is important because of the role globalisation has had in shifting production from western countries where many rights and obligations are often enshrined in law - to many parts of the developing world where business organisations tend to adopt varying levels of workplace

\footnotetext{
${ }^{1}$ Within the CSR and supply chain literature, there has been a focus upon CSR codes and compliance (see, Taylor, 2011; Egels-Zandén, 2007; Barrientos and Smith, 2007; Sinkovics et al., 2016), but little of this has extended to the compliance audit process.
} 
compliance standards (World Bank, 2007; WTO, 2004) and use social compliance audits as a response to wider stakeholder concerns (Kabeer \& Mahmud, 2004; Wilkins, 2000; Custers, 1997).

Given the increasing extent to which corporations rely upon such accreditations to legitimate their remote sourcing of products (Islam, 2009) and the increasing degree to which their western customers seem to need to legitimate their own continued purchase and consumption in a form which has the appearance of moral acceptability, it then comes as something of a surprise to appreciate how little is known about the empirical substance of the attempts by corporations, NGOs, accrediting bodies and others to ensure accountability and the integrity of the supply chain and the robustness of its claims to be in conformance with a range of seemingly impressive and important standards. This study focuses on social compliance audits: a particular process set up by MNCs to monitor the application of certain social standards within their supply chains - especially those based in developing nations. While issues associated with compliance audits are not new, research on social compliance audits has been somewhat limited and is certainly a great deal less than the research undertaken in relation to social disclosure within the context of both developed nations (see review within Deegan, 2014) and developing nations (Islam, 2010; Islam \& Deegan, 2008; Belal \& Owen, 2007; Belal \& Roberts, 2010; Deegan \& Islam, 2014; Belal et al., 2015). This is despite the fact that many corporations - particularly MNCs operating in developing nations (see, KPMG, 2008; GRI, 2011; Islam \& McPhail, 2011) - have embraced social compliance audits as a part of their social responsibility attempts. Importantly, the audit literature recognises social and environmental audits and, predominantly following Power's (1997) work, offers an increasingly robust lens through which concerns over the supply chain and its audit and assessment can be framed and explored. In a modest way this paper takes that literature and seeks to offer some initial insights into this important but little understood phenomenon.

In order to better understand the activities and motivations associated with social compliance audits, we interviewed: people working within a number of MNCs that source products from Bangladesh; people employed as external social auditors within Bangladesh; and personnel from Bangladeshi companies that supply products to those MNCs. Our results show that social compliance audits become symbolic and ritual strategies that help to maintain existing inequalities rather than being either a primary means of improving corporate accountability or a means of improving the welfare of different stakeholder groups. That is, we reveal insights that suggest that claims made by corporations that, for example, they are placing the welfare of workers at the centre of their practices might not actually be reflective of the underlying processes and motivations. We also find that a particular 'crisis' often precedes the instigation of (what we will come to know as) "external" social compliance audits: such audits are apparently believed to be more rigorous as compared with regular internal social compliance audits. Drawing on the concept of surrogate accountability (Rubeinstein, 2007), the findings suggests that to create real change in workers' conditions and to hold MNCs and their suppliers accountable, some form of surrogate (government, NGOs or media) intervention is necessary. The alternative appears to be to leave matters in the hands of 'markets' and simply wait for another incident like Rana Plaza to stir public concern. 
This study contributes to understandings of accountability (Roberts, 2009; Messner, 2009; Cooper and Owen, 2007; Cooper et al. 2003; Lehman, 2001, 1999 and 1995; Gray et al., 2014a; Medawar, 1976) by developing our understandings of the role(s) that corporate social compliance audits can play in accountability relationships. We use Rubenstein's (2007) concept of "surrogate accountability" in this research. The concept of surrogate accountability refers to the process by which accountability might be discharged in an unequal world when a third party (NGOs or media) acts as a surrogate in order to hold power wielders or powerful actors (e.g. MNCs, suppliers) accountable on behalf of accountability holders or less powerful actors (e.g. workers). The reason why such surrogate accountability might be needed is because the accountability holders (for example, workers in our study) are weak, uneducated, dependent, poor, and marginalized and are not in a position to hold power wielders accountable. External accounts produced by surrogates or societal groups can provide an important mechanism by which it becomes possible to hold powerful actors accountable (Thomson et al., 2015). As the notions of accountability highlighted by the extant accounting literature are broadly generic and primarily normative, they do not necessarily help us develop active practices of accountability in those ubiquitous situations where the power of the parties is notably unequal (Gray et al, 2014). Rubenstein's (2007) concept of surrogate accountability is therefore helpful in helping us analyse corporate accountability practices within the context of a developing country: one which exhibits high power distance, significant inequality and poverty.

The balance of this paper is structured as follows. In the next section, Section 2, we will explore the background of the social compliance audit and review the prior research. Section 3 provides a review of the supply chains of MNCs in the clothing industry which source products from a developing nation such as Bangladesh. In Section 4 we provide some theoretical perspectives to potentially explain why such organisations instigate social compliance audits. Section 5 discusses our research methods including interview process and Section 6 provides the results of interviews. Section 7 provides discussion and conclusion.

\section{Social compliance audits and prior research}

Social compliance audits can be defined as an instrument to measure, monitor and evaluate an organisation's performance with respect to its social policies and objectives. Social compliance audits come in many forms. In line with Owen (2007), Owen et al. (2000) and Gray (2000), one can argue that there can be two mutually exclusive objectives of social compliance audits. On the one hand, they can be undertaken for management control purposes: for assessing risk, managing stakeholders, image management, public relations, seeking out opportunities and efficiencies, publicising that the organisation is living by its values, and/or for maintaining legitimacy. By contrast, social compliance audits might be undertaken for accountability, democratic, and sustainability purposes with the aim of benefiting society through an understanding of how the pursuit of an organisation's objectives is, or is not, contributing to social welfare. Under this latter perspective, consideration would be given to stakeholders' rights to information, balancing power with responsibility, empowering stakeholders, or owning up to eco-justice and ecological footprint 
failures. Thus, a 'social compliance audit' is a term which can be used widely and might include anything from, on the one hand, operations undertaken by large organisations (using either internal auditors or external experts) to monitor and assess their own processes and/or procedures through to, on the other hand, explicit attempts by civil society groups (by noncorporate external and independent civic organisations, independent NGOs and so on) to hold governments and organisations to account (Cooper et al, 2005; Gray et al, 2014a).

Generally, when independent civil society is the source of the audits, then terms such as 'independent social audits', 'shadow-accounts' 'external accounts' or 'counter-accounts' are more helpful and capture more of the intention and conflict inherent in these attempts to develop accountability amongst those very reluctant to do so voluntarily (Medawar, 1976; Adams, 2004; Gallhofer et al, 2006; Gray et al., 2014; Gray, 1997; Dey et al., 2011; Thomson et al., 2015; Owen et al, 2000). When the focus of the audits for a social issue is upon managerial preoccupations, then these are more akin to management driven social compliance audit. Here, social compliance audits might be conducted by internal or external audit teams and might be undertaken voluntarily, or as a required part of a supply agreement. They can be undertaken with the aim of establishing whether an organisation is complying with its own (or other recognised) principles and standards (Gray, 2000). In this sense they are a tool by which an organisation can plan, manage and measure its 'social responsibility activities' and monitor both internal and external consequences of these activities ${ }^{2}$.

It is the management driven social compliance audit (either using internal auditors or with the help of external experts) and not the 'counter accounts' or 'civil society driven social compliance audits $^{3}$, (Gray et al, 2014) with which we are primarily concerned here. But at the same time, we do, to a degree at least, consider perceptions of NGOs (and other surrogates) as one of the factors influencing management in their decision to undertake their social compliance audits. Surprisingly, despite the considerable attention given to social audits generally within the social accounting literature and the obvious relevance of internal audits to compliance auditing generally (Cahill, 1998; Elad, 2001), this literature reveals relatively little work specifically on the social audits as compliance audits. There is, it must be said, a substantial coverage of issues of compliance in specialist literature in, for example, medicine, engineering, public policy, operations and production management, and international standards but even the increasingly important literature concerned with monitoring and controlling the supply-chain (see, for example, Locke and Romis, 2007)

\footnotetext{
${ }^{2}$ However, Thomson et al., (2015) argue that civil society driven external accounts, rather than management driven audits or accounts, justify some form of organisational corrective intervention and creates new visibilities and knowledge of existing situations in order to change or oppose something regarded as socially harmful. Civil society driven accounts and audit are embedded within struggles for power, resources and ability to govern (Thomson et al., 2015). Importantly, while management driven accounts or audits facilitates governance at a distance (Miller and O'Leary, 1993), civil society driven accounts or audit facilitates resistance, conflicts and counter action at a distance (Thomson et al., 2015) and hold powerful actors more accountable (Rubenstein, 2007). Some other research (for example Edgley et al., 2010) emphases stakeholder dialogic process in the audit and assurance practices which may also create resistance and conflicts.

${ }^{3}$ We should perhaps note that such an emphasis is not intended to privilege one approach over another: the need for future research to further investigate civil society driven social compliance audits (such as "counter accounts') as a means to develop corporate transparency and accountability is probably self-evident.
} 
seems to have made little inroad into the accounting and social accounting literatures. Given the increasing 'shrillness' of corporate claims regarding responsibility and sustainability; in light of the growing importance of the accreditation of such matters as fair trade or sustainable forestry, for example; considering the steady interest that the (social) accounting literature has in sustainability reporting; and in recognition of the importance and understanding of auditing procedures and the craft itself, an exploration of the social compliance audit seems long overdue for the accounting literature. This apparent research lacunae in the social accounting literature needs to be addressed. We remain unclear as to such questions as: What is it that such an audit seeks to audit? Is it abuses of human rights or is it simply processual? Are such audits homogeneous? Is audit expertise an issue (Gendron et al., 2007) and what determines sufficiency (Carrington, 2010)? What is made auditable and why? How is the power differential manifest in general and in an unequal world? What are the roles of NGOs (both qua NGOs and qua surrogates) in the social compliance audit process? Once we problematize the supply chain and its audit, the extent of our ignorance becomes apparent and the potential range of questions becomes huge.

Although there has been a transformation in both what we should understand by audit and how we conceive of the auditing process itself (Power, 2007) as well as an explosion in the activities and processes to which the technologies of audit are applied (Free et al, 2009), there remains considerable uncertainty around which of the many functions an audit might be serving at any one point; the extent to which its complex ambiguities are understood by those commissioning and deploying the audit and how an audit comes to acquire its credibility and legitimacy (O'Dwyer et al, 2011; Free et al, 2009; Funnell \& Wade, 2012). What is certain is that we have come a long way from the view that an audit is a simple technology essentially adding reliability to a set of regulated financial numbers - a rational evidence-based process of determining accuracy and reliability. Audit is a 'technologising' process (Power, 1991) which is a central response to, and a component of, neo-liberal institutionalization (Power, 1997). It is a problem-simplifying practice (Power, 1991, p38) reducing processes to that which is auditable and thereby gaining legitimacy and an aura of objectivity (O'Dwyer et al, 2011). It seems highly probable that the gaze of the audit is culturally determined and its meaning and interpretation constantly contested (Power, 1991; Sikka et al, 1998). There is also much that is ritualistic in audit and it may well be that this sense of ritual has the capacity to cover up conflicts in order to maintain social legitimacy of the audit and that which is audited (as Mills and Bettner, 1992) and that, in all probability, the ritual itself, the routinisation, actually lends audit its efficacy and legitimacy (as MacLullich, 2003). But as Power (2007) makes clear: there is always likely to be a least some ambiguity in the understanding of the audit and so whilst a critical lens may typically see technologies of legitimation: and a managerial lens may typically see rational attempts at improvement; these may not be incompatible.

It is clear that legitimacy is central to the newer understandings of an audit: the processes that legitimate the audit itself and, somewhat less clearly, legitimating relationships, organisations and activities. In a sense, this is less a question about what sort of legitimacy is being threatened (as O'Dwyer et al, 2011 explore) and more a question about what is being legitimated, how and why? As both Locke and Romis (2007) and Free et al. (2009) show in 
very different ways it is the narratives and discourse that the audit is seeking to legitimate by, amongst other things, seeking to dominate the discourse and ensuring that one privileged narrative is ascendant. This helps us understand what Power (1997a) means when he talks about the efficacy of the audit being relatively unimportant. A social compliance audit is, despite appearances, in all likelihood not designed to adjudge whether trade is indeed 'fair' or the managing of fish stocks 'sustainable' or the treatment of employees 'humane'. Rather it is to provide a focus for a series of reflexive legitimating mechanisms that, at its heart, might wish to establish that capitalism may continue the unquestioned consumption of excessive and appropriated wealth from elsewhere on the globe regardless of human and environmental impacts (Gray et al., 2014). More to the point, it seems that an audit is then one crucial part of a process that is seeking to legitimate (inter alia) the rights of a company to outsource; the rights of a consumer to buy; the rights of a company to claim to be responsible or sustainable; and, at least superfically, the rights of the workers (and their surrogates) to hold managers accountable; the credibility of the standard setting bodies; the credibility of the audit and the auditors; the appropriateness of the manufacturers and their processes and the impacts on workers and communities.

\section{Supply chains within the garment industry}

Despite the attention given social audits in the social accounting literature and the obvious resonance between social audits, compliance audits and the claims and concerns within supply chain, there has been relatively little direct attention in this literature to understanding and exploring the supply chain itself (see for example: Medawar, 1976; Adams, 2004; Gallhofer et al, 2006; Gray, 1997, 2000; Dey et al., 2011; Owen et al, 2000; Owen 2007). The relatively thin level of our understandings of social compliance audits suggests that we should adopt an exploratory approach to the empirical domain here. That decision, in turn, seems to counsel a focus on one industry from which some depth and worthwhile insight might be sought. It was in this light that the present work chose to focus on the garment industry. There were a number of reasons for this choice including, but not limited to, a familiarity and experience with the industry and the high levels of public outcry that have been evident in many western countries over supply chain concerns associated with the garment industry, especially regarding slave and child labour (see, for example, Ansett and Hantover, 2013) and worker health and safety. There is also a concern that the purposive use of accounting and related practices in the clothing supply chains affects workers in a less visible and deleterious manner (Neu et al., 2014). The market pressure for low-price garments is passed along from MNCs to the buying house (middlemen if any) and then to the supplier and finally to the workers (Neu et al., 2014). While suppliers can be regarded as more powerful than their workers, they are often powerless as far as their buyers (MNCs) are concerned (Sinkovics et al., 2016). This power imbalance has impact on suppliers' social operating practices (Islam and Deegan, 2008) and in this paper we just question whether externally imposed compliance audits (either controlled by suppliers or by the MNCs) create accountability in relation to workers' rights. Our approach is significantly different from the 
work of Sinkovics et al., (2016) that examines concerns over the relative weaknesses of suppliers in social 'value creation'.

As Mellahi et al (2010) show, the supply chain has become an increasingly central element of modern commercial activity. They define it as "the organizational crystallization of real material flows that form the life cycle of the product from cradle to grave" (p216). There is no obvious reason why this should not apply equally to service flow as well. Of course, the supply chain is crucial not just because of the strategic, economic and financial and quality issues that arise when manufacturing and other supplies are remotely sourced, but also for the ethical, social, environmental, cultural and political issues that seem inherent to it (Mellahi, 2010). To a significant degree, the values, principles and practices of the supply chain become essentially embedded in the goods and services that the (typically) western MNCs supply to their (typically) western (or at least wealthy) customers (Henriques, 2007; Marsden, 2011). As such, supply chains have begun to attract the attention of researchers. From disciplines as diverse as medicine, engineering, public policy, human resources, operations and production management, environmental management and international standards come a whole range of explorations that vary from the procedural and technical (see, for example, Hernandez, 2010) to the increasingly puzzled and frustrated (see, for example, Pedersen and Andersen, 2006; Egels-Zandén, 2007) as the diversity of practices, standards, objectives, conflicts and imponderables within supply chains begin to reveal themselves. For example, Locke and Roomis' (2007) attempts to explain the very different practices in two Mexican Nike suppliers both of which had been audited as "satisfactory", or Silva-Castenada's (2012) exploration of when evidence of failures of standards is inadmissible in palm oil certification, both suggest that greater attention needs to be paid to the monitoring, surveillance and auditing processes that sit at the heart of the supply chain. Similar conclusions are reached in the examination of standards as they are developed, negotiated and applied in such areas as agriculture, (Tzilivakis et al, 2012), marine accreditation (Gondor and Morimoto, 2011), child labour (Stigzelius and Mark-Herbert, 2009), children's rights (Carvalho, 2008) and sustainable development more widely (Bendell et al, 2011). Aside from the generally less critical and more technical concerns over how to manage such matters as the quality and reliability of the supply chain, a picture emerges from this literature of an increasing concern about the way in which standards are derived, applied and monitored. This in turn is giving rise, very appropriately, to a recognition of the mechanics of modernity and imperialism and the cultural insensitivity of such initiatives as attempts to "align the interests of the actors in the supply chain" as Pedersen and Andersen have it (2006, p228). Attempts have been made to deconstruct the issues at work in the supply chain through a focus on the standards, their derivation and their implications (see, for example, Spence and Rinaldi, 2012, Kolk and van Tulder, 2002; Leipzeiger, 2010; Weisband 2007a; 2007b). There is also an attempt to investigate codes and compliance within the clothing supply chain (see for example, Sinkovics et al., 2016). However, so far there has been no systematic attempt made to investigate the process of compliance audits within the clothing supply chains. In other words, it seems from the literature reviewed above increasingly probable that the monitoring, application and surveillance - the auditing - of this phenomenon is key to the whole process and offers a promising direction for further exploration. 
Supply chain is governed by standards of varying degrees of rigour and independence (Leipzeiger, 2010) and subject to scrutiny by those standard setting bodies. More piquantly, the relationship is also subject to scrutiny by the supplying company workers and (perhaps less dramatically) supplying company management; the local community have an important potential for surveillance and both local and western NGOs as well as national and local governments will have various significant interests in observing, monitoring, assessing and evaluating what happened within the relationship. Whatever influence and penalties these parties may be able to bring to bear upon the company whose supply chains we are examining may well pale into insignificance beside the influence this monitoring can have on the company's own relevant publics and salient stakeholders. That is, information from any of these parties has considerable potential to disrupt the company's substantive environment - as Shell, BP. Gap. Nike, Apple amongst others can attest. Simultaneously, corporations for a great number of reasons (see, for example, Gray et al, 1996; Blowfield and Murray, 2008) are more and more likely to make increasingly vocal corporate claims regarding their responsibility and sustainability and such claims, especially in the light of the growing importance of the accreditation of such matters as fair trade or sustainable forestry, for example and the continuing importance placed upon CSR reporting, come under greater scrutiny, are met with greater scepticism and are more vulnerable to counter-claims. It is into this maelstrom that the social compliance audits are placed and within which their function and significance must be assessed. Such audits fit precisely into the "[n]ew objects and practices [which are] continually being subject to audit" (Free et al, 2009, p138) and commands our attention as much for the functions that audits might serve as the meanings that might be attached to and understood from this new area of audit.

In order to more carefully explore social compliance audits we chose to focus on a single industry in order to try and gain some depth of analysis. The garment industry was chosen because over the last 20 years, MNCs within their global garment supply chain have received significant pressure from NGOs, the media and western consumers for sourcing products from suppliers that do not provide workplace conditions of the kind that would be expected, or acceptable, in the MNCs' domestic environment (Frenkel, 2001; Roberts, 2003; Kolk, \& van Tulder, 2004; Egels-Zanden \& Hyllman, 2006; Haltsonen et al., 2007; Hughes et al., 2007; Spar, 1998; Wah, 1998;). Such pressure in turn inevitably motivates the MNCs to exert pressure on suppliers to adopt workplace practices that are acceptable to western consumers (see for example Emmelhainz \& Adams, 1999; Kolk \& van Tulder, 2002; Radin, 2004; Sethi, 2002). And this is just one tip of the globalisation iceberg which homogenises cultures and silences communities in its neo-liberal embracing of anything that permits the acquisition of profit (Cooper, et al, 2003).

The clothing industry is just one of many that have been part of the development, typically with global NGOs, international labour organisation (ILO) and the United Nations, of various codes of conduct in relation to workplace practices. For example, there is a growing number of Western NGOs, labour organisations, civil society and consumer associations joining various alliances, such as the Ethical Trading Initiative (ETI) in the UK, and the Fair Labour Association (FLA) in the USA. The aims of these alliances are to advance social standards and to improve accountability in relation to labour conditions in global supply chains 
(Hughes et al., 2007). Many MNCs sourcing products from a developing nation incorporate human rights standards which are the same or similar to SA8000 ${ }^{4}$, or based on ILO's basic workplace standards, in their own codes of conduct (Islam \& McPhail, 2011). Along with their codes of conduct, many MNCs disclose their social compliance audit outcomes in media such as annual reports and stand-alone social reports (Islam \& McPhail, 2011). For example, Lindex (one of the largest Scandinavian clothing companies that source products from Bangladesh) state in their 2009 CSR report:

During 2009, Lindex conducted a total of 274 audits. Of these, 192 were initial audits, i.e. the first audit at a supplier, and 82 where re-audits. 199 were conducted by Lindex's own auditors and 75 were conducted by external companies. In a factory audit, an assessment is made in 13 different areas and each area is assigned a score of 0, 1, 2 or n/a depending on how well the requirements have been met. When each part of the Code has been given a score (0-2 or n/a) a final assessment of the factory is made. During 2009, 24 factories were on the Stop List. Infringements include incomplete or contradictory documents which result in it not being possible to verify the demand for a minimum wage or where a supplier has used factories which have not been audited and approved by Lindex for certain parts of its production. During 2009, a total of 157 suppliers and factories took part in training activities initiated by Lindex and BSCI.

If such companies are apparently both so determined to undertake systematic enquiry into their supply chain and go to the trouble of informing their stakeholders in such detail there is clearly a matter of some substance here deserving of attention ${ }^{5}$. Furthermore, putting aside for now the not-inconsiderable dangers of "western" standards being employed as the touchstone of acceptable practices, it is quite clear that accreditation with global standards forcefully suggests a considerable level of dedicated activity around the key components of a humane workplace.

\section{Accountability and social compliance audits}

In this paper we aim to examine social compliance audit practices through Rubenstein's (2007) lens of surrogate accountability. Most of the prior accountability research is driven by concerns about the ethics of organisational activity and a belief that organisations should be accountable to wider stakeholder groups (for a review, see Owen, 2008). Therefore, one of the important characteristics of the accountability model is that organisational disclosure should ideally reflect responsibility rather than, for example, power or legitimacy threats (Gray et al., 1997; also see review by Parker, 2005). More specifically, the bulk of the prior research has seen accountability as a practice which ideally reflects responsibilities to wider stakeholder groups and which is motivated by democratic concerns about the rights to

\footnotetext{
${ }^{4}$ SAI accredits qualified audit organizations to certify compliance based on SA 8000. Over 1.2 million workers are employed in over 2,100 SA8000 certified facilities in 60 countries (http://www.saintl.org/index.cfm?fuseaction=Page.viewPage\&pageId=472).

${ }^{5}$ It may not be irrelevant to note that the detail illustrated in Lindex's report would clearly involve a noninsubstantial amount of economic resources. In disclosing this detail we may well be able to infer that the company and its shareholders consider this to be money well-spent from a business case, risk and reputation management point of view.
} 
information and the means by which organisational behaviour might be controlled by society (Roberts, 2009; Cooper and Owen, 2007; Cooper et al. 2003; Lehman, 2001, 1999 and 1995; Gray et al., 1996; Medawar, 1976). Gray, et al. (1996, p.38) defines accountability as the duty to provide an account (by no means necessarily a financial account) or reckoning of those actions for which one is held accountable. Cooper and Owen (2007) posits that, to say that one is accountable is to expect that one would explain, justify and take responsibility for the actions or behaviour being considered. Similarly, Messner (2009, p.920) considers accountability as the exchange of reasons for the conduct that is to give an account means to provide reasons for one's behaviour, to explain and justify what one did and did not do. Each of these accountability notions is basically fairly general and only in their detail might they be considered context specific. More specifically, as the notions of accountability are primarily normative, they do not necessarily help us develop active practices of accountability in those ubiquitous situations where the power of the parties is notably unequal (Gray et al, 2014). In order to overcome this limitation and to advance the concept of accountability, we adopt in this paper, Rubenstein's (2007) concept of surrogate accountability to help us analyse corporate accountability practices within context of a developing country with high power distance, significant inequality and poverty.

Cooper \& Owen, (2007) argue that free dialogue between stakeholders is essential for any real organisational accountability. Based on the notion of Habermas' 'ideal speech situation' (Habermas, 1992), Cooper \& Owen argue that all stakeholders (especially those who are relatively powerless) should participate in some form of communicative process - but without some form of formal mechanism to ensure active participation, accountability is an empty notion. Stakeholder dialogic concern is also emphasized by Edgley et al. (2010). These concerns are important in a developed country setting (such as the UK) where most of the people are educated and a degree of independence can often be assumed: how much more important are these notions when we focus upon accountability in a demonstrably unequal world where most of the people are politically weak, uneducated, dependent, poor, and marginalized. In such circumstances, stakeholders are typically not in a position to engage in any significant communicative action (although see Agyemang et al, 2009; for an alternative approach to these issues). It is in this context that Rubenstein (2007) provides a insightful and important way forward.

Rubenstein (2007) argues that the inequality between powerful actors and non-powerful actors upsets the principle of communicative equality that a standard accountability requires (Fung, 2005; Cooper and Owen, 2007). However, the processes by which less powerful actors (community members and socially disadvantaged groups such as workers in the developing country for example) are empowered are difficult, costly and very long-term in nature (Rubenstein, 2007). In these circumstances, Rubenstein argues a different approach to accountability is required whereby independent bodies (such as civil society groups, NGOs, news media) intervene on behalf of accountability holders. The civil society group that represent the oppressed group has the potential to create visibility and accountability (Thomson et al., 2015). Rubenstein calls this approach to accountability "surrogate accountability" (Rubenstein, 2007). 
The surrogate acts for the accountability holders (e.g. workers) during one or more phases of the accountability process: a) a surrogate might endorse and the power-wielder thereby recognise standards of desired performance; b) a surrogate might collect and collate information about the power-wielder's (e. g. managers') compliance with standards, and/or c) a surrogate might (help) exercise sanctions upon the power-wielder if they breach the standards, (Rubenstein, 2007, p. 624). While reducing inequality appears to be a more desirable long term strategy for making powerful actors more accountable to less powerful actors, surrogate accountability would be feasible under conditions of severe inequality (Sinkovics et al., 2016). In their public reports, corporations often make claims that they are accountable to the wider community and, particularly that they listen to the views of their employees. It is also the case that corporations may project the view that their social compliance audits and engagement with NGOs are undertaken to ensure that stakeholder views are considered and that company performance does not disadvantage various stakeholder groups. For example, the Wal-Mart Sustainability Progress Report 2010 (p. 44) refers to its social compliance audit process by stating:

At Wal-Mart Factory Workers' Voices are heard. Wal-Mart values the opportunity to interact with workers during our visits to factories. In doing so, we gain the worker's perspective on the factory, including what can be, and has been, improved. This dialogue is vital to factory improvement, and the insight provided enables our team to focus efforts on areas that can tangibly enhance the lives of workers and result in factory improvements...Throughout all parts of our company, we work with NGOs to identify areas for improvement in our business, establish new goals and verify the data we compile on each of our initiatives to ensure that we are making good progress. They work with us because they are eager as we are to see positive change in our business practices and supply chain. We thank them for their efforts and willingness to work with our company.

More generally companies often have public statements that suggest a desire to create real improvement in the working conditions in developing nations along with - and directed by consultation with stakeholders.

H\&M annual report 2007 (p.42) states:

Taking responsibility for how people and the environment are impacted by our activities is important and is essential to H\&M's success. H\&M conducts a dialogue both internally and with external stakeholders concerning how the company can develop further. It is therefore important to formulate and convey clearly how we should work, especially since H\&M does not own any factories of its own. Our products are instead produced by around 700 independent suppliers, primarily in Asia and Europe.

The Lindex CSR Report, 2009 states:

To constantly develop and improve our sustainability work, we have an ongoing dialogue with groups of stakeholders. Together we discuss what Lindex can improve and how and what the stakeholders want Lindex to report and communicate. Lindex is a member of different local networks, what are termed Brand Meetings, in Turkey, Bangladesh, India and China. Together with other international fashion companies we discuss and co-operate in order to move the CSR work forward. In Turkey, India and Bangladesh, we are also active in Round Tables. 
One important facet of social compliance audits might well be, therefore, establishing whether claims like this one concerning the voices of employees have any substance and, perhaps more significantly, whether they connect with any search or desire for actual/real changes.

The surrogate accountability model suggests that accountability of corporations to the less powerful stakeholders via NGOs or civil society organisations is one possible way forward (Belal et al., 2015). In the context of our study, we might therefore expect to be able to observe surrogate accountability in terms of involvement and actions of NGOs and media with respect to sanctions in the event of MNCs or their suppliers violating supply chain standards of performance. When NGOs and the media act as surrogates for mistreated workers it is more likely, Rubenstein argues, that MNCs or suppliers may take corrective action via changing standards and establishing workers' rights or they may even find their business no longer tenable.

While we discussed above first order surrogate accountability, Rubenstein argues that hypothetically one can imagine infinite regress of surrogate accountability, second-order surrogate accountability, third-order surrogate accountability, and so on. To explain second order surrogate accountability, Rubentein provided an example of Nike and Gap. She argues US consumers of Nike and Gap can act as second-order surrogates for workers at their (Nike and Gap's) supply factories (in developing nations) by sanctioning Nike and Gap (being first order surrogates) if Nike and Gap fail to sanction the suppliers for violating workers' rights. However, unlike Rubenstein's example, in this paper, we consider MNCs and suppliers as managerial groups who cannot be surrogates for workers and rather we consider independent NGOs as surrogates for factory workers in a developing country such as Bangladesh. While we largely restrict our analysis to the first order surrogate accountability, further research is suggested to consider advanced-order surrogate accountability. Furthermore, while the surrogate accountability mechanism does 'matter', it is not free from criticism (KoenigArchibugi and Macdonald, 2013, p. 518).

\section{Research method}

This is an interview-based study focussing on clothing MNCs that source garments from Bangladesh. All relevant interviews were conducted in December 2009, January 2010, December 2014 and January 2015. Additionally, four follow-up interviews were conducted in September 2015. The interview participants were located in Dhaka, the capital city of Bangladesh, where the country's garment industry is based. Bangladesh presented itself as the location for data collection for a number of reasons. Not only was one of the researchers familiar with it and had good access to companies and other participants in the country, but additionally the country is one that relies upon exporting products to developed countries and it is known that social compliance audits are employed here by MNCs and their suppliers. One co-author's prior interactions with the industry actors and his association with Dhaka University Accounting Alumni (one Alumni is an official of BGMEA, another alumni is a partner of PwC's agent in Bangladesh) helped the researchers find relevant actors who were engaged in social compliance audits. Before we started interviews, we also sought the advice 
of a corporate manager from an MNC and two officials from BGMEA ${ }^{6}$. We chose interviews as a research method because through interviews we were able to gain access, gain insights, build trust and discuss matters which would not have been possible via secondary research methods.

A range of interviewees were sought so that we might gain a range of points of view from a number of different participants in the social compliance audit process. While through our prior research we already knew much about the context, the initial contacts helped us to know more about relevant participants ${ }^{7}$ dealing with compliance and social compliance audit related activities. As part of the process of identifying potential interviewees we also reviewed secondary sources such as BGMEA archives, ILO archives, as well as corporate annual reports and media releases. This process identified a list of 23 people split more or less evenly across the three groups we came to focus upon. These three groups comprised: (i) the company representatives from the MNCs who either commissioned and/or undertook the supply chain social compliance audits on behalf of their employers ('MNC internal auditors' hereafter); (ii) those who were commissioned to conduct the audits as external auditors or consultants ('external auditors' hereafter); and (iii) those who worked for the local manufacturing companies that supplied the garments and, in their role as senior managers, were either subject to audits and/or undertook their own audits internally ('suppliers' hereafter). Of the 23 people approached for an interview, 2 declined to be interviewed ${ }^{8}$. In addition, we undertook 4 follow-up interviews in mid-2015 (two representatives from two MNCs and two external auditors). Based on one co-author's long term research interactions with top level industry actors, we were able to select key players from different groups (MNCs, suppliers, NGOs, audit firms) who were engaged in the social compliance audit process. The interviewees from different groups provided deep insight into the social compliance audit process within the MNCs' supply chain in Bangladesh.

Detail about the eventual 23 interviewees is shown in the Appendix to this paper. The 7 'MNC internal auditors' were all in charge of a compliance audit division (and thus part of the internal audit management) of their companies during the period of data collection. Their observations give us a substantial insight into 4 major MNCs in the industry. The 8 'external auditors' were selected from a range of organisations intimately involved with social compliance audit. As most of the external auditors were appointed by management, we were

\footnotetext{
6 The BGMEA is a member of the Bangladesh Employers federation and, understandably, occupies a nonneutral position in this research. BGMEA itself is subject to direct NGO pressure (see, for example, http://www.sacw.net/article3430.html). There is published research (whose provenance is difficult to judge) that suggests that BGMEA's activities have advanced the cause of the workers (see, for example, Rahman \& Hossein, 2010).

${ }^{7}$ Whilst this is not an ideal method of sampling, it was the best available to us, as introductions and guidance were needed throughout the process. We have been unable to detect any obvious biased effect of taking our sample from these sources.

${ }^{8}$ Inevitably a key group to interview are the employees and it is apposite to make mention of the absence of interviews with them. This was a deliberate (and informed) action based on pilot interviews with labour representatives; the tensions that firm-directed interviews with workers would have raised, the difficulty of interpreting the range of workers in the event of taking a more $a d$ lib approach to contacting employees plus the concerns expressed by ethics clearance at university level. Given the focus of the audit itself, our judgement is that we are likely to have missed little direct relevance by this approach - although a more critical take on the legitimating processes would suggest a different and more penetrating analysis (Cooper et al., 2005).
} 
not hoping that these respondents have a full degree of independence from the MNCs to protect workers' rights. Three of those interviewed worked at an accounting firm affiliated with PricewaterhouseCoopers $(\mathrm{PwC})$ and were senior staff within the social audit division. Of the remaining five, three were external consultants (one local consultant and another representative of a foreign consulting firm); and, two were senior officials from two local NGOs (one person was an Free Labour Association (FLA, USA) auditor, and another person was funded by the Canadian International Development Agency (CIDA) to monitor garment workers' rights $)^{9}$. Finally, the 'suppliers' were represented by eight senior managers from major local garments manufacturing and supply organisations. These are the organisations from which major MNCs source their products. Of the eight interviewed, four had held senior positions within the BGMEA at some point in the past. As mentioned earlier, four interviews were subsequent "checking" interviews following up any changes over time.

This group of 23 interviewees represent a cross section of those associated with the social compliance audit process via a range of different roles. They claimed between 6 and 25 years' experience (average of 13 years). All participants suggested that they were directly involved in the strategic decision making of their respective organisations. As a result, we perceive them to be knowledgeable about the social compliance audit operations and strategies of their organisation and the impression gained was that the numbers interviewed were sufficient to allow theoretical interpretation of a particular context ${ }^{10}$.

Consistent with prior research (see for example, Islam and Deegan, 2008; Deegan and Blomquist, 2006), we developed a semi-structured interview guide so that the process was flexible enough to allow space for various views on social compliance and related audits to emerge. Interviews ranged from half an hour to three hours in length. All interviews were conducted in person. Whenever possible, interviews were audio recorded and subsequently transcribed. In cases where taping was not possible, extensive notes were taken during the interview.

Some of the text from the interviews will be reproduced within this paper where it is considered to be reflective of the opinions of the group. Whilst the details of these interviewees appear in the Appendix, the interviewees were referred to by a coded number. The code (MNC internal audit 1-7; external auditor 1-8; supplier 1-8), does not necessarily reflect the order in which they appear in the appendix. This is intended to preserve the anonymity of respondents to as great a degree as possible whilst still allowing sufficient information to be provided about the respondents. Such approach is consistent with the interview method outlined in Islam and Deegan, 2008.

\footnotetext{
${ }^{9}$ We found these two local NGOs with foreign affiliation were actively engaged in workplace monitoring and social welfare activities so as to protect the interest of garments workers in the global supply chains.

10 For each of the three groups of interviewees, the interviews led us to conclude that additional or new interviewee/s were unlikely to add new information or to add to the overall story on social audits in the garments industry. For each group, if there is homogeneity among population, a sample of six interviews may be justified to enable development of meanings, themes and useful interpretations and this informed the selection of interviewees (Guest, Bunce and Johnson, 2006). The number of interviewees is consistent with prior social and environmental accounting research (see for example, Islam \& Deegan, 2008; Deegan \& Blomquist, 2006).
} 
In developing the semi-structure interview questions we relied upon the following research questions. While interviewees were allowed scope to freely talk about various social compliance audit related issues, these research questions provided the basis for our interview questions.

1. What is the nature of the social compliance auditing that MNCs undertake to monitor the activities of their suppliers in Bangladesh?

2. What motivates the initiation of a social compliance audit?

3. Which stakeholders do social compliance auditors engage as a part of the auditing?

4. What perceptions do local suppliers have in respect of the social compliance audits and associated activities implemented by MNCs?

5. What input do local workers have to the social compliance audit process?

6. Do social compliance audits ultimately change workplace conditions?

\section{Findings}

\subsection{Nature of social compliance audit practices}

All participants were asked to provide a background to the social compliance audit practices with which they were involved. All interviewees emphasised the compliance nature of the audit $^{11}$. All audits appeared to have the central objective of determining whether MNCs sourcing garments from manufacturers in Bangladesh were doing so from organisations that appear to comply with acceptable global social standards. In relation to acceptable social standards, particular reference was made to in-house codes of conduct/standards developed by MNCs, and to ILO standards, SA 8000 and European standards such as Business Social Compliance Initiative (BSCI). There appeared to be a widely held view that the different codes and standards being used to guide the compliance audits exhibit a high degree of commonality and consistency. This is helpful but the codes and standards themselves are unlikely to offer a direct challenge to matters such as social inequality and worker discrimination (Barrientos and Smith, 2007). So the absence of any direct influence from the accountability holders such as the workers and the local community is overcome, not by the standards themselves but by the use made of those standards by the international standard setters such as ILO or BSCI. Potentially at least, these organisations act as surrogates for workers and the community and potentially help to protect their interests.

Rubenstein's (2007) concept of surrogate accountability in relation to standards posits that in an unequal situation, standard setters come with certain standards to protect accountability holders (in our case workers and the local community). Suppliers were expected to be aware of the required standards and to ensure compliance therewith. As a chairman of one major supply company stated (who was also an industry official on a labour rights organisation):

\footnotetext{
11 It rapidly became clear that although a range of terms such as social audit, compliance audit and social compliance audit were used - they were used interchangeably and as far as it is possible to tell, all related to precisely the same basic notion of auditing compliance.
} 
Buyers and authorised bodies and individuals nominated by the buyers (internal or third party auditors) have identified a number of issues for us to follow (typically included within social codes of conducts). The audit is basically to see whether we have complied with these requirements [supplier 4].

In relation to issues covered by the social compliance audit, most of the interviewees explained that the audits mainly focus on factory working conditions. As one of the auditors of a major global clothing and sports retail company stated:

In our social compliance audit we look at issues including child labour, health and safety, discrimination, compliance with law, forced and prison labour, working hours, harassment and abuse, notice and record keeping, and wages and benefits [MNC internal audit 5].

This range of issues was typical of those most noted by the interviewees as being the focus of the audits. The issues highlighted by the interviewees are consistent with the global standard setters' (such as ILO, SA8000) prescribed social standards, which are set to protect rights of the workers and the local community. This implies that global standard setting bodies are communicating their standards (or information sharing) with both suppliers and MNCs. In the absence of the democratic power of workers or the local community, standard setters apply their power to protect workers or local community; this view is consistent with Rubenstein's (2007) concept of surrogate accountability on standard and information. The considerations of the suggested standards in the audit process suggest that there is communication and information sharing occurring between MNCs and global standard setters.

The processes employed by both the MNCs internal auditors and external auditors appeared to be broadly consistent. There was also agreement that audits for new suppliers were different to periodic audits undertaken for existing suppliers. Greater effort was taken in relation to potential new suppliers and there was an expectation that suppliers pay at least some of the costs of the audit (although some audits were also paid for by MNCs). As one internal auditor of a multinational buying company stated:

We charge $\$ 1350$ (USD) for the first audit and $\$ 1090$ for subsequent audits. After the first audit, and if we find some issues that need to be addressed, we give them 120 to 160 days to resolve the issues and after that we do subsequent audits. If we find aggregated violation of various social standards, such as use of child labour, we immediately eliminate the factories as a potential source of any products. In Bangladesh we, the internal auditors, do these audits but in Pakistan we use third party auditors to do that because we do not have our own experts there. [MNC internal audit 5].

As a further reflection of the reduced activities performed on audits, other than first time audits, an external auditor from a major audit firm stated:

A first time audit is very tiring, it requires time and many things we need to follow but when we complete first audits it is easy for us to do follow up audits. When we set the time for audits with the manufacturer, the time is not specific. For example we can say we will come to your factory anytime between $13^{\text {th }}$ and $25^{\text {th }}$ of June. Then when we go for a full day audit, this is a little bit unannounced as we don't provide specific dates for the audit, we follow available social standards we have; it is mainly something directly adopted from BSCI. While the first audit addresses each and every issue carefully, in the subsequent audits we just 
concentrate on the issues which suppliers have not complied with previously. The level of compliance influences the extent of follow up audits [external auditor 4].

The impression gained from the interviewees was that the first time audits are undertaken to uncover breaches of acceptable social standards but when follow up audits are undertaken they are very much scaled back unless particular breaches have previously been identified or if particular news has come to light that social performance problems may be present. Such insights raise issues about the continuing effectiveness of social compliance audits in uncovering poor practices. Such insights also provide an interesting notion of the application or implementation of global social standards as suggested by ILO, BSCI or SA8000. If there is a breach of surrogate standards by particular suppliers, auditors are supposed to take the responsibility to sanction the suppliers. Rubenstein's (2007) concept of surrogate accountability in relation to sanction provides an interesting base to explain such sanction. While auditors theoretically have the power to protect the interest of the workers, their power can be used to benefit economic and legitimacy requirements rather than creating any real change. We will discuss this issue in detail in the next section.

Many teams appeared to follow similar audit procedures - typically with five broad elements. As one internal auditor of a multinational company stated:

We pursue five steps in completing a full day audit. First we have an opening meeting with management. In this meeting we clear our plan of actions, we also request them to be honest and transparent and cooperate in respect of allowing access to their workers, accessing necessary documents, and so forth. Then we go do our floor visits; we have a number of health and safety standards to check when we have physical visits; we do have a check list for these, additionally we also check whether they have under age workers that should be investigated. Then after floor visits we do document checking. Here for example we check employee salary sheets, age records, attendances, license checking (such as environmental clearing certificate, fire license, boiler operation license). Then in the fourth step, we interview workers; we interview young looking workers, female and male workers separately, workers from different divisions including dying sections, cutting sections, sewing sections, finishing sections, and packaging sections. We undertake random selections of workers. Finally we complete the auditing with a closing meeting with the top management. We discuss aspects relating to cooperation, and non-cooperation if any. We might demand further information, clarification and assistance as needed. We leave them without providing our audit findings. We send them our findings or discuss our findings with management the following day, or some other day [MNC internal audit 5]

While certain social standards were the key focus of the audit and the five steps of the audit were conducted by the auditors to see whether and how the standards were implemented, as evidence from the interview response, all relevant actors, including accountability holders (workers) and surrogates (standards producers, trade unions, NGOs), were not contacted by either auditors or managers to discuss audit results. However, we see that social compliance audit results were publicly available as these were communicated by MNCs through their CSR and annual reports. Based on opinions provided by the participants of this study, our understanding of the social compliance audit process suggests that limited input and feedback was required from workers, trade unions, local NGOs or even standard setters such as ILO to complete the audit process. 
Ignoring for the moment the impact of the cost on the manufacturers (as referred by external auditor 5), it is clear that the audit must be a fairly perfunctory affair. It is no wonder that the audit is "tiring" (as referred by external auditor 4): in that single day the auditor will speak with management asking them to be "honest and transparent and to cooperate", before making a physical visit and walking through their checklist of surrogates' (ILO's) recommended social standards, which is followed by detailed document checking, then interviewing employees before a closing meeting with management, (the five steps referred to by MNC internal auditor 5 above). That any assessment of substance can be performed in that time for that price is surprising and these very significant constraints again inevitably raise questions about the various stated and actual purposes of the audit.

From the interviews we got a sense that the auditors went into the field with the intention of completing their onsite investigations within a day ${ }^{12}$. Whether this coincides with what western consumers believe is happening is questionable. Nevertheless, a 'social compliance audit' is undertaken and the MNCs can report this to a wide range interested stakeholder groups (albeit that many of them do not disclose the period of time undertaken on the audit and some of them might not disclose at all if managers find that the audit results are commercially sensitive). In establishing the time constraints for the audit before the audit begins, the auditors are clearly in danger of determining what can and what cannot be done: regardless of what needs to be done to undertake a compelling audit.

MNC internal auditors appeared to follow company policies and guidelines which they check for compliance. As mentioned earlier, compliance policies and guidelines are basically based on international social standards. External or third party auditors often merge globally acceptable standards (say ILO principles on human rights, BSCI, FLA guidelines) with their clients' guidelines and policies. Interestingly, company codes of conduct and external auditor's adopted principles appear similar as they all focus on ILOs basic human rights standards. As one executive of a local NGO which is an affiliated audit partner of the FLA stated:

We are an FLA [Free Labour Association in USA) affiliated auditor. When we go for a factory visit we require both FLA guidelines, which are basically based on ILO's basic standards, and our client's (multinational companies) own standards. We also must respect local labour laws which are also overlapping with ILO standards [external auditor 5].

Basically, such audits are generally conducted by internal auditors (those who are employed by MNCs), they are typified as 'compliance audits' and their initial purpose is to reach a conclusion on the extent to which the manufacturers are in compliance with extant codes. The dominant format of these codes was that from BSCI but the codes were generally perceived as convergent, complimentary and perhaps even, inter-changeable. The interview responses suggest that external or third party auditors are more inclined to apply global standards than internal auditors who basically consider company guidelines which are themselves based on international guidelines. The significance of employing external auditors is that they are believed to be relatively independent bodies and receiving assurance from these bodies

\footnotetext{
${ }^{12}$ Some audits could potentially take longer than a single day, but we did not explore this particular aspect in the interviews. The norm appeared to be the single day audit.
} 
creates a sense of legitimacy. MNCs appoint external auditors in order to respond to legitimacy crises (we will discuss this in the next section) and such corporate driven external audit via NGOs may not nurture the spirit of surrogate accountability. MNCs appointed NGOs as external auditors (like indepependent financial auditors) may not create accountability as they are largely dependent on audit fees by their clients.

The centrality of the surrogates' recommended codes/standards and the use of checklist to provide comfort on conformance with those codes/standards (mentioned by several of the auditors unprompted) was then used as the basis upon which to articulate the outcome of the audit in the form of a rating process that might take the form of:

.....acceptable”, ...acceptable with issues,... needs improvement... [and] unacceptable [MNC internal audit 5].

or

$$
\text { “green... orange ... and red.." [MNC internal audit 2]. }
$$

Thus immediately we can see the audit is designed to use the codes/standards both as the principal mechanism of legitimation and as a means to ensure the simplification and manifestation of the complex imponderables of humane working conditions and such subtle and contested notions as human rights. The human condition is reduced to 'the code' and then the code is reduced to a checklist which can be represented in a rating of, for example, three traffic light colours. The stark clarity with which workplace experience is technologized and made auditable is arresting.

The overriding impression is that the various social compliance audits follow a fairly similar process in terms of procedures being undertaken, the ratings being provided, and social standards being followed. As mentioned earlier, standard setters' standards are being considered in the audit process: while internal auditors use the integrated standards with MNCs' codes of conduct, external auditors directly refer to international standards such as ILO or BSCI standards to complete their audits. This was something that we were previously unaware of. Having gained some knowledge of the nature of the social compliance audits, the next issue we sought to investigate was perceptions about what drives the instigation of social compliance audits.

\subsection{Motivation behind the social compliance audit practices}

Interviewees were asked why they believed the social compliance audits were instigated in the first place. Interviewees explained that a central reason is that they are a buyers' requirement and that audits would not be undertaken in the absence of a demand from MNCs. This is interesting to see how MNCs directly or indirectly imposed globally acceptable social standards imposed upon their suppliers. From the manufacturers' and suppliers' perspectives, social compliance audits are effectively mandatory given that social compliance audits typically come with every order placed. This was seen to represent a departure from the requirements of 10 to 15 years ago when the main issues of concern were cost and product quality. As a senior executive of a supply company stated: 
Yes the social compliance audit is the buyers' requirement. ...... This is a pre-condition of finalising and executing any order with the buyers. We have to sell our products and that's why we must follow certain codes of social conduct as required by the buyers [supplier 3].

It is not, clearly, though an empty ritual. In an unequal world, the audit is a substantive manifestation of the power that the MNCs exercise over the manufacturer and it is a manifestation with very real consequences.

Whilst audits may well be broadly comparable from one manufacturer to another, from one auditor to another and from one MNC to another: they do appear to be highly responsive to external influence. The most notable of these differences arose from discussion about when the external - as opposed to the MNCs' internal auditors are brought in. One unexpected insight that emerged from the interviews was that MNCs employ external or third party auditors only when the MNC faces a major threat as a result of media accusations and/or sustained NGO campaigns (such as the use of child labour, or any other inappropriate behaviour by the suppliers). As mentioned earlier, a group of surrogates (NGOs and media) are expected to sanction accountability wielders (MNCs and their suppliers) if they breach the social standards (Rubenstein, 2007). We found opinions that external auditors were appointed to respond to the possible threats of sanctions by NGOs and media. The power of NGOs and media are emphasized here. Prior research (for example, Thomson et al., 2015) demonstrates that external accounts by social movement organisations intend to challenge and de-legitimate power relations in order to mobilise change agendas in the social movement and create accountability. There was a belief that the involvement of third parties increases the likelihood that information would be accepted or believed by various stakeholder groups. Information provided by third parties is considered to have greater credibility. There appeared to be a belief that external third party reviews are an instrument for corrective action, and as a means to pacify concerned stakeholders.

As one external auditor stated:

You may be aware that MNCs are often criticised because of a belief that their supply sources are not ethical. There have been many incidents that the western news media has frequently highlighted such as showing pictures' and videos' of children working in the factories; this could be in the Wall-Mart factories, Gap factories, Nike factories and so on. NGOs and labour right bodies often take actions against many MNCs for not being responsible: for not meeting maternity leave expectations, for paying poor wages, or for massive fire accidents.......... group of NGOs and labour rights took action in a US court against Wal-Mart for poor working conditions and underpayments in its supply factories. We saw many of these being very sensitive as western consumers react so quickly to these events. These sorts of events have led to the appointment of third party auditors who are believed to be more credible agents to investigate these matters. We found concerned multinational companies usually take corrective actions based on our audit outcomes particularly when a crisis leads the companies to appoint us [external auditors 2].

An internal auditor of a multinational company also stated: 
When something goes wrong, you can imagine third party auditing is imminent. You can expect our headquarters in USA to directly assign an accounting firm or NGO to investigate the incidents and to make public the existence of the third party involvement [MNC internal audit 2].

There was a perceived crisis as surrogates such as media and NGOs threatened to impose sanctions due to the violation of particular social standards (also see Thomson et al., 2015). When - as a result of an incident like the media's discovery of child workers, and when surrogates are about to sanction - concerned MNCs and their suppliers employ external auditors. This context for employing external auditors has never been researched before.

Hence again, we very much get the feeling that social compliance audits are about addressing legitimacy threats and protecting brand image rather than being motivated by any underlying ethical reasoning. The greater the media attention or perceptions about the severity of the potential crisis, the greater the perceived likelihood that third parties would be involved in the audit practice. These results are broadly consistent with the large body of literature which generally suggests that the nature of social disclosures and associated practices, is reactive to legitimacy threatening events (Deegan, 2002). Although such legitimacy threatening incidents and associated possible sanctions by surrogates influenced management to make an appointment of a third party auditor, this may not create change any improvement of working condition.

\subsection{Stakeholder dialogue and inclusion as a part of social compliance audit process}

As we showed earlier in this paper, MNCs often make public statements that suggest that stakeholder dialogue and stakeholder inclusion is an integral part of the audit and compliance process. However, the majority of the interviewees indicated that their audit programs did not have provision to engage people outside of the factories. In other words, surrogates' feedback was not considered in the entire process. This is primarily consistent with assurance research (see, Edgley et al., 2010) that identified significant obstacles to stakeholder dialogue in sustainability assurance practices. Indeed there was a degree of scepticism about the need, in normal circumstances, to talk to people outside of the organisation such as labour leaders, NGOs or the local community. One representative response was:

It is a common and regular exercise to interview a sample of workers and mid and top managers of the factories as a part of social compliance audit. No other people are considered necessary to contribute to the audit process [external auditors 1].

However, like the use of third party auditors, the extent of external stakeholder engagement also appeared to be reactive to the existence of a legitimacy crisis. As one external auditor noted:

When there is a media campaign... or labour unrest... we interview outside people adjacent to the factory as they are believed to have some important information. These people may be shop keepers, people gossiping in the tea stall, and so on [MNC internal audit 2].

When asked whether there is a need to talk to NGOs and human rights organisations as a part of the audit, all of the interviews (except two) said that in normal circumstances there would be no need to talk to external people. As one internal auditor noted: 
We don't have to talk to NGOs or the local community unless we are instructed from the head office to do so. In the normal circumstances we can manage the situation internally, so why should we talk to the local community or to NGOs or even to the media? This might only inflame an issue.[MNC internal audit 3].

This is inconsistent with how MNCs often publicly describe their social compliance audit engagement processes (in corporate media such as annual reports or sustainability reports). This all suggested that despite our attempts to remain superficially anodyne in the questioning that the 'surrogate' question may have been seen as threatening and maybe explained why our interviewees were unable to help us to speak to the local communities or, more appositely, the actual employees.

All the internal auditors were asked whether they knew about whether any other stakeholder groups or representatives could get access to the workers in the factory. The typical response is that they 'rarely engage NGOs, labour leaders or journalists to monitor supply practices [MNC internal audit 3].

The data seemed to consistently suggest that whilst the audit was a simple, straightforward and perfunctory activity when everything was "normal" and "under control", once the gaze of external parties, notably in the west, alighted upon the supply chain, a different undertaking was launched. It seemed to us quite clear that the appointment of the external auditors was not a question of competence, (crises in the company were, as far as we could tell, dealt within the company), but a question of perceived authority and competence. Surrogate intervention through highlighting legitimacy threatening incidents mean that repairing and regaining legitimacy required a very different perceived posture than when one is simply maintaining that legitimacy.

When there is a real crisis, the MNCs were more likely to require the social compliance audits be undertaken by a third party - often an NGO body. To get rid of a real crisis, the use of NGOs as third party auditors can at best be seen as "co-option" technique as part of corporate manipulation strategies explained by Oliver (1991).

Furthermore, it transpires that where NGOs were appointed they considered themselves to be acting as both auditors and as external stakeholders. Two of the NGOs interviewed said they monitor activities in their role as an auditor as well as in the role of a stakeholder who protects workers' interests.

When we enter a factory we interview workers and they open up to us and we discuss their problems and hold discussions with the managers to resolve the problems. It is good that some companies are monitored by us. We are protecting the workers' interests [external audit 5].

It was not apparent either that such NGOs also undertook wider stakeholder consultation, assuming, apparently, that their role as NGO made such additional dialogue unnecessary. This apparent lack of consultation with external parties such as NGOs or labour leaders, unless it is deemed necessary for addressing a particular crisis, was unexpected. Furthermore, when NGOs are somehow appointed by managers to audit working conditions, they appear to lose their independence and they may not be called 'surrogate'. NGOs' dual interest in the social compliance audit process needs to be investigated further. The findings also indicate that irrespective of their engagement with management (in the audit process), NGOs and 
labour leaders in an unequal world may not be powerful enough to hold the power wielder accountable and protect the workers' rights.

\subsection{Clothing manufacturers' perceptions of social compliance audits}

Officials from all eight of the garment manufacturing firms were asked general questions about their perceptions of social compliance audits and the tensions the activities create. All interviewees considered that they are subject to pressure during the audit as audit outputs might lead to the cancellation of orders. One typical response included:

This provides huge mental tension for us. We are always in fear of losing our contract [supplier 2].

Although a number of the interviewees appeared to struggle to see real benefits from undertaking a social compliance audit, some of the suppliers considered there were some limited benefits. They said a good audit report in itself can create financial benefits (interestingly, no mention was made of the benefits to employees).

The audit brings benefit to us if we get a good report from the auditor. We are doing business with the international partners. If one partner gives us a good compliance report we can sell it to other prospective buyers. During the period in which we are negotiating a new order reference to a good audit report becomes very effective. Compliance has a financial value to us! [supplier 5].

The above response gives a sense of financial rationale behind the social compliance audits. In other words, if there is no pressure from consumers and there is no financial benefit of carrying out a social compliance audit, it seems likely that an audit would not be carried out. More importantly (to our mind), suppliers when interviewed did not volunteer any suggestions that they are creating change in order to improve the working conditions.

When auditors (both internal and external) were asked about the pressures or tensions caused by their factory visits they said they understood that manufacturers felt significant pressure for fear of losing contracts. One external auditor stated:

Irrespective of the nature and type, an audit is a source of pressure and tension. ... when we go for factory visits and talk to random workers, managers do not know how workers answer our questions. Workers might say, child workers are used here, they might say they are sexually harassed or physically assaulted. These are all gross violations of social standards. For any of these violations, the factory would be suspended or multinationals can cancel order. This is very costly [external auditor 1].

Reflecting on the perceptions from the local suppliers it was interesting that none of the suppliers apparently considered the benefits that social compliance audits might create for employees. Rather, they saw social compliance audits as a potentially costly exercise that could only create benefits (of a financial nature) if the outcome of the audit was positive. Such results are generally consistent with Islam and Deegan, (2008) who found that the disclosure of social performance information reflected the expectations of MNCs, rather than because of any underlying ethical reasoning pertaining to accountability. What we observe here is that while standard setters - such as ILO being (either first order or second order) 
surrogates - have imposed certain social standards upon both suppliers and MNCs at the first phase of the accountability process, NGOs and media, being another group of surrogates, are sometimes not powerful enough to execute the second (information) and third (sanction) phases of accountability. We are not clear as to whether surrogates, NGOs and media or standard setters such as ILO receive any real information about MNCs' and suppliers' compliance with standards. We observe that without a threatening incident, in an unequal world surrogates do not fully sanction MNCs or suppliers for non-compliance. Because of their weak position, accountability holders cannot sanction (or play their role in helping to sanction) (Rubenstein, 2007, p. 624) MNCs or suppliers; the power of surrogates needs to be strengthened to make MNCs and their partners ethically accountable. Therefore, any form of weak accountability only encourages the power wielder to be opportunistic and, in effect, contribute to existing inequity.

\subsection{Local workers' input as part of audit process}

As we have seen, stakeholder involvement in the audit process was generally low (also see Edgley et al., 2010) although all parties seem to expect that workers would be interviewed as part of the process. The process diminished stakeholders' access to receive real information about MNCs and suppliers' compliance with a particular social standards. In terms of the input that workers had to the social compliance audits, the following representative responses were provided:

We interview workers, we select some, and employers also select some for us to interview [MNC internal auditor 4].

It is a core audit step that we talk to workers; we have a questionnaire for them. Whatever we ask workers we give the managers a general idea of it. Whatever answers we get from workers we provide aggregate results to the manufacturers. We call them in a room where there is no camera; worker selection is random. [external auditor 1].

In terms of the conduct of the interviews:

We create environments to get information. We interview individually and we also interview in a group, it is very effective because if one worker says something, others agree or disagree and others can correct if someone goes wrong or somebody tells a lie, they have eye contact with each other, this is an interesting way to collect information about what actually is going on. [MNC internal audit 2].

Generally, it is the auditor who selects the workers to be interviewed. Many of the workers are perceived to be uncomfortable in identifying problems because of the implications that could follow for both themselves and the organisation. Such levels of discomfort are not consistent with the public commitments disclosed by the MNCs. Rather such levels of discomfort give a clear difference of actual actions from the ritualistic practice or the use of social compliance audits.

The auditors (internal and external) were also asked whether audit outcomes are shared with the workers. The results indicated that there is no direct communication with workers about the audit outcomes or about the level of importance that the auditors attributed to their various concerns. Three representative responses included: 
While workers are allowed to respond to our guided questions, and to raise arguments around them, we never ask open questions. We never discuss with workers that their particular arguments have been accepted or particular complaints have been solved [external auditor 3].

.... We only discuss the issues which managers need to address and correct. This discussion is only with managers, we don't go to workers for further discussions [MNC internal auditor 3].

We disclose specific audit outcomes neither to workers nor to management [MNC internal auditor 1].

During follow up interviews, when we asked interviewees about the possible implication of providing audit feedback to workers, one interviewee was really critical about the possible role of the workers. According to him, providing some audit feedback could be a high risk for the managers and employers. As he stated:

You know the context of Bangladesh right? Why should we share audit results with workers? We discuss audit outcomes with managers and suggest if corrective measures are needed. Now if we find workers are underpaid and if we share this result with workers, they will simply put fire to the factory. Can you imagine some devastating consequences of sharing some audit finding with workers? (Follow up interview: external auditor 8).

From the above responses, although the workers voices are heard in the audit process, it is difficult to know to what extent the workers were (and perceived themselves to be) free from coercion. The auditors and suppliers appeared to recognise that the employees being accountability holders would have fears about providing negative information and it is clear that the level of dialogue was limited (Edgley et al., 2010) through both the restriction on the use of open questions and the lack of follow-up in terms of how the organisation was to address particular concerns. There is no sense here that the welfare of workers is paramount. From a surrogate accountability perspective (Rubenstein, 20007) this is the case in the unequal world where accountability holders such as workers are less powerful because of their weak vulnerable situation within the organisations. Given this situation one may question why employees' input, not surrogates' input is necessary to complete the audit process. The audits seem almost ritualistic so as to provide the basis for social compliance with the requirements imposed by MNCs. If engagement with the stakeholders is ritualistic and potentially manipulative then such processes will not necessarily advance the interests of less powerful stakeholders, albeit that the actions might be economically rational from the perspective of the organisation (Wadham, 2009). Again, we had the feeling that the nature of the social compliance audits were such that they were not being conducted to improve the welfare of workers, but were undertaken in some form of ritualistic manner so as to provide the basis for compliance with the requirements imposed by MNCs. As we discussed in the prior section, there was a pressure of surveillance and such pressures clearly derives of its power from the the symbolic power of the audit (Power, 2007). Notably, there seems to be relatively little conflict or even potential for conflicts within the audit process itself: as Power (1991) would suggest, the audit is a problemsimplifying practice. In part this seems to be achieved by the focus of the social compliance audit being predominantly upon the compliance with codes and not upon the condition of the workers and communities. 
Given our concern about whether the social compliance audits were creating positive outcomes for workers, the last issue we explored in our interviews was whether, from the perspective of the interviewees, real social benefits accrued as a result of the social compliance auditing activities. This is important to know because the power wielders (MNCs and suppliers), accountability holders (workers) and surrogates (ILOs, NGOs, media)), at least at ritualistic level, talk about the process of social compliance audits which is itself worker centric.

\subsection{Social compliance audits as a means of improving working conditions?}

Towards the end of the interviews, when the interviewee had typically become a little more relaxed and trusting, one of the key purported issues within the social compliance audits, the changing condition of workers (Question 6), was addressed ${ }^{13}$ : despite the potential ritualistic nature of the audit, have humane working conditions and community rights improved at all? Views were muted and somewhat mixed. In essence, there appeared to be a sense that there was change but it was slight and, potentially, only temporary. In explaining how the audits led to improved working conditions, one representative response was:

.... The continuous monitoring by internal and external parties [NGOs, media] gives workers a sense that if MNCs try to do business with suppliers in Bangladesh then both parties have to follow social standards. Is this not a good change? [external auditors 7].

The surrogates' role undertaken by NGOs and media are evident in influencing accountability practices by MNCs. However, as discussed earlier, NGOs' campaign and media allegations against MNCs are not of a continuous nature that could hold MNCs accountable in a perpetual manner.

So what is being achieved? Time and again the auditors expressed their principal concern as being their ability to give assurance to the MNC that the surrogates' suggested code(s) was being complied with. Unfortunately, we were unable to engage any responses which reflected upon either the limitations of that ambition or the potential irony of such an achievement in this constrained setting. However, it seemed very important that the auditors represented themselves as undertaking something significantly more than a simple box-checking exercise. In terms of how economic sanctions seem to motivate workplace improvements, one typical response included:

We suspend factories if they don't comply with certain issues such as ensuring workers are not physically or sexually harassed; or workers are underpaid. We definitively will cancel an order if we find any young looking workers and there is no explanation. We are very strict in following these standards. We have huge product sourcing from Bangladeshi manufacturers; they want to work with a big buyer like us as. They know our expectations and the majority of them behave and change accordingly [MNC internal auditor 2].

Thus, as Mills and Bettner (1992) and MacLullich (2003), for example, have argued, it is essential to legitimate the audit as a routine of some substance and import in order to distract attention from the perfunctory ritual its actual practice seems to be.

\footnotetext{
${ }^{13}$ Given our earlier concerns about appearing to be anodyne, this question was something of a gamble (albeit an essential one). Coming at the end of the interviews and typically following from discussion of the "not normal", the question appears to receive a good response.
} 
A number of the external auditors and internal auditors suggested that factory managers are motivated by their own self-interest and would probably stop ensuring certain conditions were met if monitoring was discontinued. A minority of the respondents also questioned whether any real change had occurred:

I don't think the workers' real situations have changed as we expected. Change is very slow in terms of human rights. There is a gap between buyers' commitment and what is really happening here. ..... Auditor can identify the problems, they can talk to managers to solve these problems but problems are so deep rooted that audits sometimes have nothing to do but to identify problems that might be solved [external auditor 6].

Those who provided negative comments were asked what MNCs and suppliers should do to create fundamental change in working conditions. All said the problem is endemic in poor economies like Bangladesh - an unequal world where workers are less powerful to fight for their own rights and where surrogates such as NGOs and media can substitute for workers to hold power wielders accountable (Rubenstein, 2007). While the surrogates' accountability mechanism can help in the short to medium term (Rubenstein, 2007), policy reform at a national level and mandatory governance or audit requirements, along with exercising real democracy, might assist in reducing violations of human rights in a sustainable manner.

Neither buyers nor suppliers alone can solve child labour and other human rights problems. Now buyers are putting pressures on suppliers because of NGO and media campaigns; but how long will such pressure be maintained? It has brought change but perhaps it would be better if governments - both host and home governments - imposed requirements for multinational companies to appoint independent auditors and mandated a requirement that audit reports must be communicated with workers and other stakeholders who in turn might protect workers' interest - such as labour rights NGOs. This could reduce some problems. Without independent third party involvement any possible benefits to workers will be hampered [external auditor 5].

Of some interest, the recognitions that workers' conditions may not be improving did not play back onto a questioning of the role of the social compliance audit itself but, more importantly, (in a manner which both Free et al, 2009; and Locke and Roomis, 2007 suggested) was then couched with excuses as to why this was not the fault of audit.

Although the above responses appear to suggest that the social compliance audit process brings positive change, those changes appear to be both operating on the suppliers' (and MNCs') financial self-interest and fundamentally temporary and reversible in nature. Only substantive structural governance change seems likely to embed positive initiatives - a situation which seems to obtain in many areas of poverty within developing countries. The above responses again suggest that the current processes employed within the context of Bangladesh (at least as experienced by our group of interviewees) fall short of actual accountability (or standard accountability, see Rubenstein, 2007) or action wherein the interests of affected stakeholders are advanced through a process of open and free engagement without fear of subsequent discrimination.

After the Rana Plaza collapse -a terrible incident of a building collapse which killed more than 1100 garments workers in Bangladesh in April, 2013(Odhikar, 2013; Burke, 2013), we conducted four follow up interviews (2015) (two with external auditors and two with MNC 
internal auditors) to understand whether anything changed in the social compliance audit practices within the supply chains. We received mixed responses. An MNC compliance audit chief stated that there has been no change in their social compliance audit process. A third party auditor stated that before the Rana Plaza incident the structural problem of the factory building was part of the social compliance audits often overlooked and neglected by the auditors in their audit process, however after the incident, due to massive international pressure, separate or independent building inspections or building safety audits have been introduced by most of the suppliers as per guidelines provided by two international compliance accreditation bodies in Bangladesh including Accord and Alliance. Key opinions included here:

I do not see much change in the audit process. But before the Rana Plaza incident, we did not realise a factory building could collapse and kill many people. The incident has just shaken the whole industry and made everyone realise that building safety is the most important issue of compliance. The issue was never considered as a serious issue of concern. I would say the issue of audit change but not the audit process (Follow up interview: MNC internal auditor 4).

..... After the Rana Plaza incident, we now do independent building fire and safety audits (which is different from other social compliance audits) where we look at the entire process (from checking building permits to checking raw material used for the building). (Follow up interview: external auditor 8).

We did not find any change in the mechanisms or understandings of accountability in the social compliance audit process as a result of the Rana Plaza incident. However, the incident itself suggests that a new form of audit, this being a building safety audit, has emerged, which is beyond the scope of this paper. However further research is required to investigate building safety audits within the global supply chains.

Any improvements in working conditions that are made appear to occur because of threats to the suppliers of losing contracts. That is, only threats or coercive pressures are likely to address accountability to some extent. However, where positive changes are made there was a feeling from some interviewees that such changes should not be considered permanent or firmly entrenched. There was a view that if the social compliance audits ceased then many positive initiatives would cease and accountability collapse. This led some interviewees to suggest that some form of surrogate (government, NGOs or media) intervention was necessary, rather than leaving it in the hands of 'markets' where product quality, time and price pressures affect workers in unintended and deleterious ways (Neu et al., 2014). The view was that if the advancement of workers' rights is left to market forces then real sustained structural changes in workers' conditions will either not occur, or will be slow in coming. The continuance of such change would in particular be dependent upon the media and NGOs continuing to be active in bringing the plight of workers to the attention of western consumers. Whilst there has been some positive changes over recent decades, the slowness in change inevitably causes frustration for workers, but they tend to be relatively powerless to change the situation. This frustration at times leads to campaigns of labour unrest in the Bangladeshi garments sector via protests, which in turn attracts media attention and potential reputational risks for MNCs (BBC, 2010; The Guardian, 2010; Ethical Trade, 2009; ILRF, 2011). There was a view that such campaigns are a necessary strategy for workers to keep 
the focus of western consumers on workplace issues within the context of a developing country.

\section{Discussion and conclusion}

In this paper we have sought to explore the practice of using social compliance audits within the context of a developing country, specifically Bangladesh. We have found that social compliance audits are typically a necessary precondition to MNCs entering supply contracts with Bangladeshi suppliers. Nevertheless, whilst such practices are common in the supply chain, there is little detail within the accounting literature about how these audits are undertaken and the motivations behind the audit process. While prior research focussed on assurance practices, certification systems or compliance audits both in the accounting and business literature, exploration of the social compliance audits and, especially, the employment of in-depth fieldwork has been relatively scarce. This paper adopts a rich interview-based approach in an attempt to partially address this gap. Part of our research goal was to fill this lacuna and to provide a description about what actually happens when 'social compliance audits' are undertaken within a developing country.

In attempting to understand the nature of the social compliance audits we set out to see if the processes being employed might be usefully interpreted through the notion of surrogate accountabilty. In undertaking our research, we interviewed 23 individuals within Bangladesh who had sound knowledge of the practices of social compliance auditing being performed. Our results suggest that the audits are not typically improving workers' rights and where they are, they occur because of the financial penalties that would otherwise be imposed on suppliers (through loss of contracts). We also learned that there appears to be a great deal of similarity in the process of audits being performed across the garments industry of Bangladesh and that the extent of work performed, and the involvement of third parties, appeared to be influenced by whether a potential crisis has been identified in relation to a particular supplier. Conversely, if nothing negative has been identified with respect to contracted suppliers (perhaps through the media or by NGOs) then ongoing auditing is reduced in scope. That is, stakeholders or surrogates' (NGOs and media in particular) threats and pressures are likely to help restore accountability. If surrogates' threats ceased, then many positive initiatives would cease.

What seems to have emerged is a complex interplay of motives, assumptions and influences. The actual conduct of a social compliance audit is predominantly a requirement instituted by the MNC as a pre-condition of the supply contract. There is very little evidence that, all things being equal, the MNCs exert much in the way of resources or effort to assess the reliability of these audits which appear to have a symbolic role and allow the MNC to continue to make claims that appear to play well with western consumers. In a climate of CSR one might, albeit naively, have thought that the MNCs would have had strong intrinsic and extrinsic motives for ensuring that the audits were substantive and that the claims were reliable. There is no evidence of this. Consequently, the audits are generally of a cursory nature and we found little evidence that they make much constructive impact on the lives of workers and communities. Such accountability as is owed to the relatively powerless workers 
and communities remains largely undischarged. (It did, however, look as though conditions might worsen should even these cursory audits disappear). But that is by no means the whole story. In any ways the most influential actors are, what Rubenstein calls, the "surrogates": NGOs, civil society organisations, social and news media and so on who, independently and on behalf of the accountability holders, monitor and expose failures in the conditions in the supply chain. These surrogates have the power to expose and embarrass all segments of the supply chain and, crucially, the auditors themselves, by identifying unreliable claims and overlooked issues which the international codes suggest are important. The actions of the surrogates raise issues and, as we have seen, occasionally result in the allegedly more rigorous external auditors being called in. Whether these auditors merely constitute a more legitimate form of symbolic action is a moot point. What seems clear is that without the very existence of the surrogates and the potential action that they might undertake, the social compliance audits would, in all probability, be even more meaningless than they are now. What little accountability is present in the supply chain appears to owe its discharge, as Rubenstein rightly observes, to the power and actions of the surrogates.

The findings suggest that to create real change in workers' conditions and hold MNCs and their suppliers accountable, some form of surrogate (government, NGOs or media) intervention is necessary, rather than leaving it in the hands of 'markets' and waiting for another incident like Rana Plaza. Thus, a social compliance audit becomes a ritualistic practice that supports MNCs' maintenance of legitimacy to the wider community rather than creating real accountability. The findings suggest that 'counter accounts' (Gray et. al., 2014; Thomson et al., 2015) can be used by surrogates in a radical manner to bring real changes in the social compliance audit practices.

Once again, from the various responses documented in the paper, the story which emerges here is a complex one which resonates well with the emerging audit literature - especially in that the social compliance audit is not a monolithic discourse. Not only, as Power (2007) makes clear, is the audit simultaneously both a rational managerialist attempt at improvement and a legitimating process, but it is not a single thing, not a single activity. At a minimum, the social compliance audits comprise two quite different characters. For most of its life, it is a calming, routinized, maintenance of both order and the appearance of order. The audit is a successful combination of a problem-simplifying technology, of routine and superficiality but bound around with a language and aura of symbolic legitimacy and an appeal through its panopticon character to the threat of real economic penalty. This ritual is played out and is both legitimated by and helps legitimate the surrogates' suggested codes (such as ILO's ones) and guidelines that successfully convey a notion of appropriate beneficence that the MNCs are happy to exploit through their reporting and other information dissemination mechanisms. There is an entirely other audit process when surrogates' sanction (such as NGOs' protest resulting in labour unrest or media's highlight of child labour) is mobilised - when the maintenance of "normal" has failed. The symbolic legitimacy of the "external auditor" is then called upon and their "professional" symbolic legitimacy is brought to bear in the firefighting, deflecting surrogates' sanction and criticism and repairing legitimacy. And these more serious and more substantial auditors engage a wider range of surrogates (including NGOs, media, local community, labour leaders) - although whether to be seen to do so; 
whether in order to identify and defuse trouble-makers; or whether for both purposes was unclear to us. There is nothing in the audit process which is actually designed to accept surrogates' voices and identify and reduce the risk of the MNCs. There is simply not enough work undertaken for the real risks - whether to workers or to the MNCs to emerge and/or to be identified. It is as Power $(1997 \mathrm{a} / \mathrm{b} ; 2007)$ has argued - the existence of the audit which matters - its efficacy is of no importance.

A number of persuasive, if tentative, inferences can be drawn from the enquiry. We have found that social compliance audits are a necessary precondition for MNCs entering supply contracts with Bangladeshi suppliers. How widespread this might be would be worthy of further investigation. Our respondents identified a high degree of convergence between the different codes and social standards under which social compliance audits are conducted and there was a noticeable degree of agreement on the issues and the procedures which inform the audit. On this latter point, for illustration, child and/or forced labour, health and safety and discrimination rank highly. Environmental and community issues do not. These agreements seemed to be independent of background or function and seemed, as far as one could tell, to be independent of cultural context - at least at a superficial level. It also emerged that the social compliance audits are typically fairly perfunctory and follow-up audits, superficial or non-existent. The bulk of our respondents seemed to be of the view that "external" auditors offered the more credible option in times of legitimacy threats from the western media and/or civil society organisations. While such legitimacy threats are likely to create a sense of accountability to some extent, it is unsustainable. The absence of accountability will return soon after the legitimacy threats are gone. Like prior research that looked at codes for labour practices (Barrientos and Smith, 2007), our study reveals that social compliance audit process that also assesses the implementation of the codes, has limited merit to challenge existing social inequality or unequal world in the workplace. As a key element in the surrogate accountability process, NGOs and civil society groups need to be empowered to create continued democratic concern and discursive communicative action so that workers' rights are protected in an unequal world like Bangladesh. In an unequal world, surrogates (deliberative activists in Fung's (2005) term) may lack ability to alter the deep structure of inequality. Dialogic engagement processes are important to nurture 'multiple actionsincluding organisation-centred accounts as well as a variety of external accounts- that can authentically reconstruct this diversity of interests' (Thomson et al., 2015, p.814; also see Edgley et al., 2010). At a broader level, surrogate accountability requires altering the deep structure of inequality through empowerment of surrogates -much of this deserves further research attention. Most importantly the robustness of external and civil society groups' claim to represent the oppressed group deserve further research attention (Thomson, et al., 2015). Furthermore, while we acknowledge that with surrogate accountability mechanism alone may not be fully capable of making powerful actors accountable, there is a room for further research to investigate whether surrogate accountability relationships operate alone or in a mixed systems alongside standard accountability (Koenig-Archibugi and Macdonald, 2013).

Most importantly, all of the evidence we collated spoke of the social compliance audits as business-driven events with two principal functions. The first function was that of identifying 
and minimising risk to the purchasing companies, MNCs. This risk related to concerns that information concerning practices that western customers and NGOs found unacceptable might find its way into the public domain. The second principal function was directly related to this: the very act of using garment manufacturers in developing nations (for clear economic reasons) is an act which needs legitimating in the eye of western customers and NGOs. However, these two principal functions did not lead to any apparent improvement of working conditions or real accountability in relation to those working conditions. The social compliance audits serve this legitimating function by creating a significant distance from the real action to improve working conditions. How well the audits actually fulfil these functions is a more telling question:

- First, the issues of risk may well be worth further enquiry. It was far from obvious that the perfunctory and ritualistic nature of the audit could be relied upon to regularly identify potential areas of risk as they affected the MNCs. Although not specifically investigated, the audit functions may well be that its presence is relied upon to encourage appropriate self-disciplining and self-audit amongst the suppliers.

- Second, it would be tempting to characterise the social compliance audits as rituals of legitimation whose purpose was to be seen and perceived, not to find or to change. What the MNCs' relevant publics think is happening in a social compliance audit and what is actually happening are quite different things. There is certainly no evidence that the function is to ensure structural long term change in the conditions of the workers and their communities - however we interpret such an ambition.

- Finally, of the issues our initial review anticipated might arise, the absence of any explicit concern over matters of culture and/or the aligning values is arresting. The only explicit appearance of such a concern was the recognition that these audits are a requirement of the MNCs and, more pertinently, that the emphasis in the audits has developed (from quality to conditions) - thereby reflecting changing values of the MNCs with which the suppliers must comply. It may well be that it is the absence which deserves more attention. That is, are social compliance audits and the imposition of values from the west so engrained that they are no longer remarked upon? That this whole process is just one more part of the imperialism of western capitalism seems incontrovertible. This is one sign of process among many that highlights the contradictions and irrationalities which are systemic to capitalism (Belal et al., 2015). The one thing the social compliance audits do not seem to be is a mechanism through which the betterment of peoples and communities might be rigorously pursued.

We acknowledge that the results reported in this paper emanate from one country only, and from a fairly limited number of interviewees (23). Nevertheless, these respondents had high levels of experience in the practice of social compliance auditing within Bangladesh and the nature of the responses across the group were generally consistent in relation to the various issues associated with the nature of the audit engagements, the motivations driving the instigation of the social compliance audits, and the outcomes that arose. So, whilst the sample used in this study is not without limitations, we believe our insights do provide the basis for 
questioning the public claims that many MNCs have made, and continue to make, about their auditing processes and surrogate engagement mechanisms. We did not interview any managers based in the head office of the concerned MNCs, so we are unsure about the possible variations of responses between managers sitting in the head office and managers in the direct supply chain. Although managers in the direct supply chain are more knowledgeable in the audit process than managers based in the head office, there is a scope for further research to document the opinions of managers in the head offices. As our key focus of this paper is the management driven social compliance audits, we largely overlooked civil society driven social audits. Civil society driven audit is also an important area of research and we invite researchers to investigate this issue as in-depth evidence gathering from NGOs, civil society organisations, media, trade unions is clearly beyond the scope of this paper. We simply encourage other researchers to pursue this line of investigation. 


\section{References}

Adams, C. 2004. The ethical, social and environmental reporting-performance portrayal gap. Accounting", Auditing and Accountability Journal, 17 (5): 731-757.

Agyemang, G., Awumbila, M. \& O'Dwyer, B. 2009 A critical reflection on the use of focus groups as a research method: lessons from trying to hear the voices of NGO beneficiaries in Ghana, Social and Environmental Accountability Journal. 29, 1, p. 4-16,

Ansett S. \& Hantover J. 2013. Bangladesh factory fires - the hidden dangers of subcontracting, Ethical Corporation Magazine, $5^{\text {th }}$ February: http://www.ethicalcorp.com/supplychains/bangladesh-factory-fires-\%E2\%80\%93-hidden-dangers-subcontracting.

Belal, A. R., Cooper, S. M., \& Khan, N. A. 2015. Corporate environmental responsibility and accountability: What chance in vulnerable Bangladesh? Critical Perspectives on Accounting, Forthcoming

Ball, A., Owen, D.L. and Gray, R. (2000). "External transparency or internal capture? The role of third-party statements in adding value to corporate environmental reports." Business Strategy and the Environment, 9(1): 1-23

Banerjee, S. B. 2007. Corporate social responsibility: The good, the bad and the ugly (Cheltenham: Edward Elgar).

Beder, S. 2006. Suiting themselves: how corporations drive the global agenda (London: Earthscan).

Belal, A., \& Cooper, S. 2011. Absence of Corporate Social Reporting in Bangladesh: A Research Note, Critical Perspectives on Accounting, 22 (7) 654-67.

Belal, A. \& Roberts, R.W. 2010. Stakeholders' perceptions of corporate social reporting in Bangladesh, Journal of Business Ethics, 97(6), 311-24.

Belal A. R. \& Owen D. 2007. The views of corporate managers on the current state of, and future prospects for, social reporting in Bangladesh: an engagement based study. Accounting, Auditing and Accountability Journal, 20(3):472-94.

Barrientos, S. and Smith, S. 2007. Do workers benefit from ethical trade? Assessing codes of labour practice in global production systems, Third World Quarterly, 28 (4), 713-729.

Bendell, J. Miller, A \& Wortmann, K. 2011. Public Policies for Scaling Corporate Responsibility Standards: expanding collaborative governance for sustainable development, Sustainability, Accounting, Management \& Policy Journal , 1 (2)

Blowfield, M , \& Murray, A. 2008 . Corporate responsibility : a critical introduction (Oxford: Oxford).

Boiral, O. 2007. Corporate greening through ISO 14001: A rational myth? Organization Science, 18(1), 127-146.

Burchell, S, Clubb C, Hopwood, A, Hughes, J, \& Nahapiet, J. 1980. The roles of accounting in organisations and society, Accounting, Organizations and Society, 5 (1), 5-27.

Burke, J. 2013. Bangladesh Factory Collapse Leaves Trail of Shattered Lives, http://www.theguardian.com/world/2013/jun/06/bangladesh-factory-building-collapsecommunity.

Carvalho E. 2008. Measuring children's rights: An alternative approach, International Journal of Children's Rights 15, 545-563.

Cahill, L, B. 1998. The value-added compliance audit. Internal Auditor, 55 (3).

Cameron, G. \& Neu, D. 2003. Accounting for globalization, Accounting Forum, 27(4), 449-471.

Carrington, T. 2010, An analysis of the demands on a sufficient audit: Professional appearance is what counts!, Critical Perspectives on Accounting, 21 (8), 669-682.

Carvalho, E. 2008, Measuring children's rights: An alternative approach", International Journal of Children's Rights, 15: 545-563.

Cooper, C, Taylor, P, Smith, N, \& Catchpowle, L. 2005. A discussion of the political potential of social accounting, Critical Perspectives on Accounting , 16(7): 951-974.

Cooper, C.,Neu, D, \& Lehman, G. 2003, Globalisation and its discontents: a concern about growth and globalization, Accounting Forum, 27 (4), 359-364.

Cooper, S. \& Owen, D., 2007, Corporate Social Reporting and Stakeholder Accountability: The Missing Link, Accounting, Organizations and Society, 32 (7-8), 649-67. 
Cooper C., Neu, D. and Lehman, G. 2003. Globalisation and its discontents: a concern about growth and globalization" Accounting Forum 27(4), 359-364.

Christmann, P., \& Taylor, G. 2006. Firm self-regulation through international certifiable standards: Determinants of symbolic versus substantive implementation. Journal of International Business Studies, 37(6), 863-878.

Cohen, J. R. \& Simnett, R. 2015. CSR and Assurance Services: A Research Agenda, Auditing: A Journal of Practice \& Theory, 34(1):59-74.Darnall, N., Seol, I. \& Sarkis, J. 2009. Perceived stakeholder influences and organizations' use of environmental audits, Accounting, Organizations and Society, 34 (2):170-87.

Deegan, C. 2014, Financial Accounting Theory, $4^{\text {th }}$ edn. Sydney: McGraw Hill. Deegan, C. 2009, Financial Accounting Theory, $3^{\text {th }}$ edn. Sydney: McGraw Hill.

Deegan, C, \& Blomquist, C. 2006, Stakeholder influence on corporate reporting: an exploration of the interaction between WWF-Australian and the Australian minerals industry. Accounting, Organizations and Society, 31: 343-372.

Deegan, C., Cooper, B. \& Shelly, M. 2006a. An investigation of TBL report assurance statements: Australian evidence, Australian Accounting Review. 16(39):2-18.

Deegan, C., Cooper, B.J. and Shelly, M. 2006b. An investigation of TBL report assurance statements: UK and European evidence. Managerial Auditing Journal, 21(4,): 329-71.

Deegan, C. \& Islam, M. A., 2014, 'An exploration of NGO and media efforts to influence workplace practices and associated accountability within global supply chains', The British Accounting Review, 46 (4), pp.397-415.

Dey, C 2007, 'Social accounting at Traidcraft plc: a struggle for the meaning of fair trade' Accounting, Auditing \& Accountability Journal, 20(3), 423-445.,

Dey , C. Russell, S. \& Thomson, I. 2011, Exploring the potential of shadow accounts in problematising institutional conduct. Chapter 6 in Osbourne S. and A. Ball (eds) Social Accounting and Public Management: Accountability for the common good (Abingdon: Routledge), pp.64-75.

Edgley, C. R., Jones, M. J. and Solomon, J. F. 2010. Stakeholder inclusivity in social and environmental report assurance, Accounting, Auditing and Accountability Journal, 23 (4), $532-557$.

Egels-Zandén, N. 2007. Suppliers' compliance with MNCs' codes of conduct: behind the scenes at Chinese toy suppliers, Journal of Business Ethics, 75(1), 45-62.

Egels-Zanden, N. \& Hyllman , P. 2006, Exploring the effects of union-NGO relationships on corporate responsibility: the case of the Swedish Clean Clothes Campaign, Journal of Business Ethics, 64: 303-16.

Elad, C. 2001, Auditing and governance in the Forestry Industry: Between protest and professionalism, Critical Perspectives on Accounting, 12 (5), 647-671.

Emmelhainz , M. \& Adams, R. 1999, The apparel industry response to 'sweatshop' concerns: areview and analysis of codes of conduct, Journal of Supply Chain Management, 35 (4), 5157.

Free, C. Salterio, S. \& Shearer, T. 2009, The Construction of Auditability: MBA Rankings and Assurance in Practice, Accounting, Organizations \& Society, 34 (1), 119-140.

Frenkel, S. 2001, Globalization, athletic footwear commodity chains and employment relations in China, Organisational Studies, 22 (4), 531-62.

Funnell, W.N. \& Wade, M. 2012, Negotiating the Credibility of Performance Auditing, _Critical Perspectives on Accounting, 23 (6), 434-450.

Fung, A. 2005. Deliberation before the Revolution: Towards an Ethics of Deliberative Democracy in an Unjust World, Political Theory, 33 (2), 397-419.

Gondor, D. and Morimoto, H. 2011. Role of World Wildlife Fund (WWF) and Marine Stewardship Council (MSC) in seafood eco---labelling policy in Japan, Sustainability Accounting, Management and Policy Journal, 2 (2), 214-230.

Guest, G, Bunce, A. \& Johnson, L. 2006, How many interviews are enough? An experiment with data saturation and variability, Field Methods (Sage), 18 (1), 59-82.

Gallhofer, S., Haslam, J., Monk, E. \& Roberts , C. 2006, The emancipatory potential of online 
reporting: The case of counter accounting, Accounting, Auditing and Accountability Journal, 19 (5), 681-718.

Gendron, Y., Cooper, D.J. \& Townley, B. 2007. The construction of auditing expertise in measuring government performance, Accounting, Organizations and Society, 32: 101-129.

Gray R., C. Adams \& D. Owen 2014a. Accountability, Social Responsibility and Sustainability: Accounting for society and the environment (London: Pearson)

Gray, R., Brennan, A., \& Malpas, J. 2014, New accounts: Towards a reframing of social accounting. Accounting Forum, 38(4), 258-273.

Gray, R.H. 1997, The silent practice of social accounting and corporate social reporting in companies in Zadek S,.Evans R,Pruzan P. (eds) Building Corporate Accountability: Emerging practices in social and ethical accounting, auditing and reporting (London: Earthscan), pp.201-21

Gray, R. 2000, Current developments and trends in social and environmental auditing, reporting and attestation: A review and comment, International Journal of Auditing, 4 :247-268.

Gray, R., Dey, C., Owen, D., Evans, R. \& Zadek, S., 1997, Struggling with the Praxis of Social Accounting: Stakeholders, Accountability, Audits and Procedures, Accounting, Auditing, \& Accountability Journal, 10 (3), 325-64.

Gray, R. Owen, D. and Adams, C. 1996. Accounting and accountability: social and environmental accounting in a changing world, Prentice Hall, Hemel Hempstead.

Habermas, J. 1992, Moral consciousness and communicative action, Polity Press, Cambridge

Haltsonen, I , Kourula, A. \& Salmi, A. 2007, Stakeholder pressure and socially responsible purchasing, Finance, Marketing and Production, pp.47-56.

Hernandez, H. 2010, Quality audit as a driver for compliance to ISO 9001:2008 standards, TQM Journal, 22 (4): 454-466.

Henriques , A. 2007, Corporate Truth: the limits to transparency (London: Earthscan).

Hughes, A. Buttle, M. \& Wrigley, N. 2007, Organisational geographies of corporate responsibility: a UK-US comparison of retailers' ethical trading initiatives, Journal of Economic Geography: Transnational Retail, Supply Networks, and the Global, 7 (4): 491-513.

Islam, M.A. 2010, 'Social and environmental accounting research: Major contributions and future directions for developing countries', Journal of Asia-Pacific Centre for Environmental Accountability, 16 (2): 27-43.

Islam, M. 2009. Social and environmental reporting practices of organizations operating in, or sourcing products from, a developing country: evidence from Bangladesh, $\mathrm{PhD}$ Thesis, School of Accounting and Law, RMIT University, Melbourne.

Islam, M.A. \& Deegan, C. 2010, Media pressures and corporate disclosure of social responsibility performance: A case study of two global clothing and sports Retail companies', Accounting and Business Research, 40 (2), 131-148

Islam, M.A, \& Deegan, C. 2008, Motivations for an organisation within a developing country to report social responsibility information: evidence from Bangladesh, Accounting, Auditing \& Accountability Journal, 21 (6), 850-874.

Islam, M. A. \& McPhail, K. 2011, Regulating for corporate human rights abuses: The emergence of corporate reporting on the ILO's human rights standards within the global garment manufacturing and retail industry, Critical Perspective on Accounting, 22 (8): 790-810.

Jones, M. J. \& Solomon, J. F. 2010., Social and environmental report assurance: Some interview evidence. Accounting Forum, 34 (1):20-31.

Koenig-Archibugi, M. and Macdonald, K. 2013., Accountability-by-Proxy in Transnational Non-State Governance. Governance, 26, 499-522

Kolk, A. \& van Tulder R. 2002, The effectiveness of self-regulation: corporate codes of conduct and child labour, European management Journal, 20 (3): 260-71.

Kolk, A. \& Van Tulder R. 2004, Ethics in international business: multinational approaches to child labour, Journal of World Business 39 (1): 49-60.

Lehman, G., 2001, Reclaiming the Public Sphere: Problems and Prospects for Corporate Social and Environmental Accounting, Critical Perspectives on Accounting, 12 (6), 713-33.

Lehman, G., 1999, Disclosing New Worlds: a Role for Social and Environmental Accounting and Auditing, Accounting, Organizations and Society, 24(3), 217-42. 
Lehman, G., 1995, A Legitimate Concern with Environmental Accounting, Critical Perspectives on Accounting, 6 (5), 393-413.

Leipziger D. 2010. The Corporate Responsibility Code Book Revised second edition (Sheffield: Greenleaf)

Locke, R, \& Romis, R. 2007, Improving work conditions in a global supply chain”. MIT Sloan Management Review Winter, 48 (2), 54-62.

MacLullich, K.K . 2003. The Emperor's 'new' clothes? New audit regime: insights from Foucault's technologies of the self, Critical Perspectives on Accounting, 14 (8): 791-811.

Marsden, J. 2011, Auditing, Chapter 4.3 in (eds) Brady J, Ebbage A Lunn R. Environmental management in organizations: The IEMA Handbook (London: Earthscan), pp.399-417.

Medawar, C. 1976, The social audit: a political view,. Accounting, Organizations and Society, 1(4): 389-394.

Mellahi, K, Morrell, K. \& Wood, G. 2010. The Ethical Business: challenges and controversies (London: Palgrave Macmillan).

Messner, M. 2009, The limits of accountability, Accounting, Organisations and Society, 34 (8), 918938.

Mills, S.K. \& Bettner, M.S. 1992, Ritual and conflict in the Audit Profession", Critical Perspectives on Accounting, 3(2), 185-200.

Neu, D., Rahaman, A. S., \& Everett, J. 2014., Accounting and Sweatshops: Enabling Coordination and Control in Low-Price Apparel Production Chains. Contemporary Accounting Research, 31(2), 322-346.

Odhikar 2013. Broken Dreams: A report on the Rana Plaza collapse, last accessed 15 Nov at http://odhikar.org/wp-content/uploads/2013/06/Fact-finding_RMG_Rana-Plaza_Eng.pdf

O'Dwyer, B ., Owen, D. \& Unerman, J. 2011, Seeking legitimacy for new assurance forms: The case of sustainability assurance, Accounting, Organizations and Society, 36 (1), 31-52.

O'Dwyer, B. \& Owen, D. 2005. Assurance report practice in environmental, social and sustainability reporting: perspectives of stakeholders in Ireland, The British Accounting Review, 37(2), 205229.

Oliver, C. 1991. Strategic Responses to Institutional Processes. The Academy of Management Journal, 16(1), 145-179.

Owen, D., 2008, Chronicles of Wasted time? A Personal Reflection on the Current State of, and Future Prospects for, Social and Environmental Accounting Research, Accounting, Auditing \& Accountability Journal, 21(2), 240-67.

Owen, D. 2007. Assurance practice in sustainability reporting, in Unerman, J. O'Dwyer, B. Bebbington, J. (ed) Sustainability Accounting and Accountability Routledge, pp.168-183.

Owen, D. L, Swift T. A, Humphrey, C, \& Bowerman, M. 2000, The new social audits: accountability, management capture or the agenda of social champions? European Accounting Review, 9(1): 81-98.

Parker, L., 2005, Social and Environmental Accountability Research: A View from the Commentary Box', Accounting, Auditing \& Accountability Journal, 18 (6), 842-60.

Pedersen, E.R. and Andersen, M. 2006. Safeguarding corporate social responsibility (CSR) in global supply chains: how codes of conduct are managed in buyer-supplier relationships, Journal of Public Affairs, 6 (3/4), 228-40.

Power, M. 2007, Business risk auditing: debating the history of its present Accounting, Organizations and Society, 32 (4/5), 379-382.

Power, M. (2003). Auditing and the production of legitimacy, Accounting, Organizations and Society, 28(4), 379-94.

Power M. 1997a, Expertise and the construction of relevance: accountants and the environmental audit", Accounting Organizations and Society, 22 (2) 123-146.

Power, M. 1997b. The Audit Society: Rituals of Verification, Oxford University Press, Oxford.

Power, M. 1991, Auditing and environmental expertise: Between protest and professionalization. Accounting, Auditing and Accountability, 4: 30-42

Radin, T. 2004, The effectiveness of global codes of conduct: role models that make sense, Business and Society Review, 109 (4): 415-47. 
Rahman, S. 2004, Global shift: Bangladesh garment industry in perspective, centre for development research, Bangladesh (CDRB) Publication, Dhaka.

Rahman, M. A, \& Hossain, M.S. 2010. Compliance Practices in Garment Industries in Dhaka City”, Journal of Business and Technology (Dhaka), 2: 71-87.

Roberts, S. 2003., Supply chain specific? Understanding the patchy success of ethical sourcing initiatives, Journal of Business Ethics, 44 (2-3): 159-70.

Roberts, J. 2009. No one is perfect: the limits of transparency and an ethic for 'intelligent' accountability. Accounting, Organizations and Society, 34, 957-970

Rubenstein, J. 2007., Accountability in an unequal world. Journal of Politics, 69(3), 616-632

Shelton, R.\& Wachter, K. 2005, Effects of global sourcing on textiles and apparel, Journal of Fashion Marketing and Management 9 (3), 318-29.

Sethi, S. 2002. Standards for corporate conduct in the international arena: challenges and opportunities for multinational corporations, Business and Society Review, 107 (1): 20-24.

Sikka P., Puxty, A., Willmott, H. and Cooper, C. 1998. The impossibility of eliminating the expectations gap: Some theory and some evidence, Critical Perspectives on Accounting, 9(3), 299-330.

Silva-Castaneda, L. 2012. A forest of evidence: third-party certification and multiple forms of proof a case study of oil palm plantations in Indonesia, Agriculture and Human Values, 29 (361370).

Simnett, R. Vanstraelen, A. \& Chua, W. F. 2009, Assurance on sustainability reports: An international comparison, The Accounting Review, 84(3), 937-967.

Sinkovics , N. Hoque, S.F. and Sinkovics R. R. 2016. Rana Plaza collapse aftermath: are CSR compliance and auditing pressures effective?, Accounting, Auditing \& Accountability Journal, $29(4), 617-649$.

Spar D. 1998. The spotlight and the bottom line: how multinationals export human rights, Foreign Affairs, March/April, pp.7-12.

Spence, L.J. and Rinaldi, L. 2012. Sainsbury: Embedding sustainability within the supermarket supply chain" chapter three, In Accounting for Sustainability: Practical Insights, Edited by Hopwood, A., Unerman, J, \& Fries, J. Earthscan, London

Stigzelius, I. and Mark-Herbert, C. 2009. Tailoring corporate responsibility to suppliers: Managing SA8000 in Indian garment manufacturing, Scandinavian Journal of Management, 25(1), 4656.

Taylor, M. 2011. Race you to the bottom ... and back again? The uneven development of labour codes of conduct, New Political Economy, 16 (4), 445-462.

Thielemann , U. 2000, A brief theory of the market - ethically focused. International Journal of Social Economics , 27 (1), 6-31.

Tzilivakis, J., Green, A., Warner, D.J., McGeever,K. and Lewis, K.A. 2012. A framework for practical and effective eco-labelling of food products. Sustainability Accounting, Management and Policy Journal, 3(1), 50-73.

Thomson, I. , Dey, C. and Russell, S. (2015), “Activism, arenas and accounts in conflicts over tobacco control”, Accounting, Auditing \& Accountability Journal, Vol. 28 No. 5, pp. 809-845.

Wadham, H. 2009, Talking across boundaries: business and NGO perspectives on CSR: sustainable development and partnership, Journal of Corporate Citizenship, 34: 57-68.

Wah, L. 1998, Treading the sacred ground. Management Review, 87(7), 18-22.

Wilkins, M. 2000. Globalization and human Rights: the apparel industry in the Developing World", International Affairs Review , 14 (1).

World Bank. 2007. Clothing and export diversification: still a route to growth for low income countries?, International Trade Department, The World Bank MSN MC2-201, Washington DC.

WTO. 2004. The Global textile and clothing industry post the agreement on textiles and clothing, Discussion Paper, No. 5, World Trade Organization, Geneva, Switzerland. 


\section{GLOSSARY}

BGMEA Bangladesh Garments Manufacturers and Exporters Association

BSCI Business Social Compliance Initiative

CIDA Canadian International Development Agency (CIDA)

CSR Corporate Social Responsibility

ETI Ethical Trading Initiative

FLA Fair Labor Association

ILO International Labour Organisation

ISO International Standards Organisation

MNC Multi-National Corporation

SAI Social Accountability International

NGO Non-Governmental Organisation

WTO World Trade Organisation 


\section{Appendix: Interviewees}

\section{MNC Representatives, internal social auditors and audit management (MNC internal auditors)}

Regional CSR Manager (Bangladesh, India and Pakistan) and chief of compliance audit division (Bangladesh), H\&M, A Sweden based multinational companies

Follow up communication: Regional relations responsible manager and Sustainability Intern in Bangladesh, H\&M.

CSR and compliance Project Coordinator, H\&M, A Sweden based multinational companies

Compliance coordinator and Auditor, Sears Holdings Management Corporation, SEARS and Kmart.

Compliance Auditor, Sears Holdings Management Corporation, SEARS and K-mart.

Compliance and supplier Development Specialists and auditor, Wal-Mart Global Procurement, An associate of Wal-Mart, USA.

Compliance Coordinator and auditor, Lindex Bangladesh Liaison Office ,

Follow up interview: Compliance Manager, Dewhurst, A European brand. (During his first interview, he was at SEARS Holding Management Corporation)

\section{Third party/external social/compliance auditors}

(external auditors)

Senior Team member, Compliance audit Team,

A Kashem and Co., Chartered Accountants, the representative PricewaterhouseCoopers (PwC)

Social Auditor,

A Kashem and Co., Chartered Accountants, the representative PricewaterhouseCoopers (PwC)

Chairman, Managing Director and Compliance audit specialist, Development Consultant and Global Compliance Initiative, (A

Registered Vendor with the World Bank Group)

Manager, Compliance Audit Division (1999-2008),

A Kashem and Co., Chartered Accountants, the representative of PricewaterhouseCoopers (PwC).

Currently, Manager R deR Compliance Group- representing Certification International (UK) Ltd.

Follow up interview: Compliance manager, a major garments buying house for MNCs

Senior compliance auditor

A Kashem and Co., Chartered Accountants, the representative of PricewaterhouseCoopers (PwC).

Project Coordinator and monitor, Improvement of Women Industrial worker's conditions Project, NUK (Centre for Women's Initiatives), A CIDA funded local NGO.

Executive Director and chief of compliance audit, PHULKI - a local NGO, an FLA (Free Labor Association in USA) affiliated audit body.

Follow up interview:

Country (Bangladesh) chief of Compliance, WRAP, a major global certifying body.

(during our first interview, this interviewee was at an MNC)

\section{Officials from Garments Manufacturer and supply organisations (suppliers)}

Executive Director and Company Secretary, Tallu Spinning Mills Ltd., Mithun Knitting \& Dyeing (CEPZ) Ltd., Toyo Composite Knit Garments Ltd., Pure Cotton Knitwears Ltd. Knit \& Knitwears Ltd. All are suppliers of garments to major multinational companies (Carrefour; Wal-Mart, Reebok and many others)

General Manager and Company Secretary, Desh Garments - A leading export oriented publicly traded garments company that supplies leading US companies (SEARS Holding, K-MART, Coles and many others).

Manager, Administrative and Social Compliance audit Division, Desh Garments - A leading export oriented publicly traded garments company that supplies leading US companies (SEARS Holding, K-MART, Coles and many others).

Managing Director, Bonny Apparels (Pvt.) Ltd. A supplier of major multinational buying companies. Also Chairman, BGMEA Labour Arbitration committee and member of BGMEA standing committee

Founder and president, Mohammadi Group, A leading garments manufacturers who supply goods to major US and European multinational companies (H\&M, C\&A, Zara, Esprit, Sears, Wal-Mart, Target ). He was past president, past vice president, and several times past director and present director of BGMEA

Managing Director,A\&M Knit RSSM Ltd. A supplier of major multinational buying companies. Also Deputy Secretary, Social Compliance Cell, BGMEA and the member of BGMEA-ILO project on RMG work environment.

Director, Islam Garments Industries (A group of companies), supplying garments to major US and European buying companies (Wal Mart USA, Wal Mart Canada, Otto Versand, M \& S; Lindex and many others). Also Past vice president and director of BGMEA

Managing Director, Ananta Apparels Ltd., Ananta Sportwear Ltd., Ananta Fashion Ltd., Ananta Designers Ltd. All garments are supplied to major US and European companies (GAP International, Haggar, Target Stores, Wal-Mart Canada; Woolworth, M \& S Mode and many others). Also Chairman, BGMEA social compliance cell, member of BGMEA standing committee. 
